\title{
CAUSE-EFFECT RELATIONSHIPS IN ENERGY FLOW, TROPHIC STRUCTURE, AND INTERSPECIFIC INTERACTIONS
}

\author{
Nelson G. Hairston, Jr., ${ }^{*} \dagger$ and Nelson G. Hairston, SR. $\ddagger$ \\ *Section of Ecology and Systematics, Cornell University, Ithaca, New York 14853-2701; \\ $\ddagger$ Department of Biology, University of North Carolina, Chapel Hill, North Carolina 27599-3280
}

Submitted May 6, 1991; Revised June 17, 1992; Accepted July 22, 1992

\begin{abstract}
Measurements of the efficiency of energy transfer between trophic levels are consistent with the hypothesis that it is trophic structure that controls the fraction of energy consumed at each trophic level, rather than energetics controlling trophic structure. Moreover, trophic structure is determined by competitive and predator-prey interactions. In freshwater pelagic communities, the collective efficiency of herbivorous plankton in consuming primary producers is up to 10 times as great as is the efficiency of forest herbivores in consuming their food. Conversely, forest predators are about three times as efficient in consuming herbivore production as are zooplanktivorous fish. The presence of an additional level, piscivorous fish, in pelagic communities accounts for the difference. In the aquatic system, herbivorous zooplankton are freed from predation by the effect of piscivorous fish on their predators; in the terrestrial system, green plants are freed from herbivory by predation on the herbivores. We explain the contrast between freshwater pelagic systems and forests and prairies as follows: Pelagic ecosystems have more trophic levels as a result of selection for small rapidly growing primary producers, which cannot hold space in the fluid medium, in contrast to large space-occupying producers in the terrestrial environment. Consumers in pelagic systems are more frequently gape limited in the size range of food they can ingest than are grasping consumers in terrestrial systems. This difference makes for two largely distinct levels of predators in pelagic communities. The energy within the living, nondetrital components is more finely divided between trophic levels in pelagic systems than in terrestrial systems. Ecological efficiencies do not determine trophic structure; rather, they are its product.
\end{abstract}

The relationship between trophic structure and ecological energetics appears simple until an attempt is made to establish cause and effect. Opinion about this relationship changed several times during the period that ecology was becoming established as a science, but the central hypotheses were largely in place by the mid-1960s. A considerable amount of information about ecological energetics and trophic structure has been collected during the three succeeding decades (1960s, 1970s, and 1980s). This article is an attempt to compare the original hypotheses with the published data and to synthesize the available information into a coherent picture, particularly for terrestrial and freshwater pelagic ecosystems.

Early emphasis was on the effect of energy flow on trophic structure (Lindeman 1942; Odum and Odum 1955), culminating in the suggestion that the height of the trophic pyramid is limited by energy transfer between trophic levels (Hutchinson 1959; Slobodkin 1960, 1962). A quite different approach to understanding trophic

$\dagger$ To whom correspondence should be sent. 
structure combined interspecific interactions with trophic web ecology to argue that commonly accepted observations on natural ecosystems can be explained by competitive and predator-prey interactions. It has been concluded (Hairston et al. 1960, hereafter referred to as HSS) that, in mature terrestrial communities, competition for resources is most important in the decomposer, producer, and carnivore trophic levels but that the herbivore trophic level is kept low by predation. Although HSS excluded aquatic systems from their discussion, a parallel argument has been developed for pelagic lake ecosystems. Smith (1969), working with mathematical models, concluded that the principal factor limiting each trophic level depended on the number of tropic levels present and pointed out some reasons for different numbers of levels. Earlier Hrbacek (1962) had proposed that planktivorous fish could reduce herbivorous zooplankton, which would lead to an increase in phytoplankton density. Subsequent investigations further developed this point of view from data on lakes (Brooks and Dodson 1965; Zaret and Paine 1973; Shapiro and Wright 1984; Carpenter et al. 1987), and the ideas have recently received considerable attention by both terrestrial (Fretwell 1977, 1987; Oksanen 1988, 1991; Schoener 1989) and aquatic ecologists (Persson et al. 1988; Liebold 1989).

Acceptance of the HSS conclusions would mean either that trophic efficiency is unrelated to the input of energy or, in the extension of HSS by Oksanen et al. (1981), that the two are related in complex ways. Therefore, neither constant nor regularly increasing efficiency would be found. Indeed, transfer efficiency would be determined principally by the relative importance of predation and competition and, as will be seen, by the number of trophic levels present.

\section{TOWARD A SYNTHESIS}

It is our objective here to summarize information on both trophic structure and energy flow between trophic levels for several terrestrial and pelagic ecosystem types. We use this summary to point out differences in trophic structure between these ecosystem types, most notably an apparent difference in food chain length, as well as in energy transfer efficiencies between these ecosystem types. In our summary of energy transfers between trophic levels, we principally use consumption efficiencies (the percentage of net production at level $n$ that is consumed by level $n+1)$. Although there is a wide array of other ecological efficiencies that have been used by previous investigators (Kozlovsky 1968), we have adopted this measure because it reflects the impact that consumers have on the trophic levels on which they feed, which is useful in the comparisons we make here. We also provide values for assimilation efficiency (the percentage of energy ingested at level $n$ that is assimilated at level $n$ ), and, although it is our impression that these values are often less reliable than those for consumption, the conclusions we draw are unchanged. We recognize that some readers may interpret our approach to infer that we assume equilibrium conditions. We prefer to avoid such a loaded term. The data that we use, in some cases with a range of values, rather are assumed to be representative of the ecosystem concerned, which thus implies approximate long-term averages. 
Before proceeding further, we freely acknowledge that we have concentrated on a few systems: freshwater pelagic, temperate forests, and grasslands. These are the systems that we know best, and we find contrasts among them that lead us to interesting conclusions. This is consistent with conclusions from an analysis of field experiments (Hairston 1989) that a better understanding of ecological processes can be obtained by considering them in one kind of system at a time. For other kinds of ecosystems, such as deserts and the freshwater littoral zone, some of our approach may well be applicable. These are discussed briefly at the end and could lead to further comparisons and contrasts between ecosystems. Communities of marine intertidal and subtidal zones, though well studied, are excluded from our consideration because there more than one trophic level depends on an external source of energy (i.e., they are not well-defined ecosystems). Furthermore, in these systems, up to three trophic levels may all compete for space.

We ask whether the differences we document in ecological efficiencies are the cause of the differences in food chain length (essentially the first hypothesis discussed above) or if, in contrast, differences in food chain length are the cause of the differences in ecological efficiencies (essentially the second hypothesis discussed above). It is our basic conclusion that the latter is more important than the former. We further point to a number of instances in which rates and efficiencies of energy transfer within particular communities are strongly affected by the individual characteristics of the species present. Finally, we propose an explanation for the differences in trophic structure between terrestrial and pelagic ecosystems.

TROPHIC STRUCTURE

We first consider what is the most informative way in which to represent and analyze trophic structure. Two related systems have been used in the past: the food webs ("cycles") of Elton (1927) and trophic levels, an approach initiated by Lindeman (1942). Fundamental to such an analysis is the question of community or ecosystem boundaries. This becomes a crucial issue when we ask what limits particular components of a system. Nature seems to abhor a sharp boundary as much as a vacuum, and ecosystems are no exceptions. Even so great a contrast as that between open water and forest typically shows an intermediate progression, as, for example, from cattails to buttonbush to alder thicket to trees. We recognize that classification of trophic structure in such a location can become an exercise in futility as different aspects are assigned to the two ecosystems. Ecotones may be wide bands, as those in the northern United States and southern Canada between temperate and boreal forests, or they may be interdigitating complexes, like the deciduous forest-prairie ecotone. Bird watchers know well the richness of avifauna in such locations, and Gleason (1926) made much of the gradual change from one "association" to another in his argument against community organization. The degree to which aquatic communities are distinct from bordering terrestrial and benthic systems can vary greatly: the influence of allochthonous inputs to lakes depends on such variables as length of shoreline 
and size of watershed (Rodhe 1969; Likens 1984; Wetzel 1990a). The effect of allochthonous input of leaves and branches may contribute most of the energy to stream ecosystems, especially in small streams. For example, in two creeks in Quebec, Naiman et al. (1987) found that $91.3 \%$ and $74.1 \%$, respectively, of the carbon input came from such sources, with only $4.2 \%$ and $15.9 \%$ coming from primary production. The remainder came from rainfall and throughfall. In marine shoreline systems, the settlement of planktonic larvae onto benthic substrates and their subsequent filter feeding on the plankton differ markedly between sites (Roughgarden et al. 1988), and the relative importance of organic versus reducedinorganic compounds as sources of energy moving from benthic to pelagic habitats depends on the importance of anaerobic decomposition (Howarth and Teal 1980). Less dramatic "seepage" between ecosystems comes from forest predators (hawks) on grassland herbivores or aquatic animals, such as fish and frogs. Conceptualizing ecological systems as food webs or as trophic levels gives different perspectives on this problem.

\section{Food Webs}

There are some serious difficulties in the use of food webs (several of which were raised previously by Paine [1988] and Polis [1991]). Three in particular trouble us here. The first is that quantitative assessment of the strength of even a majority of the links is rarely practicable, a problem that has led many investigators to the implicit assumption that the links are equal in value. Food webs, with their focus on unweighted interactions between individuals, can lead to an overemphasis on rare interactions. For example, Martinez (1991) assigns 25 taxa, ranging from large, abundant fish species to rare insect genera, equal importance as prey to largemouth bass inhabiting a small midwestern lake. By this method he finds over 10 food chain links from algae to bass. He does not ask, however, where the bass obtain the majority of their energy-surely not after having passed through 10 trophic levels. Similarly, among the complex food webs illustrated by Polis (1991) in his figure 7, there are at least 10 links from plants to golden eagles. If the consumption and assimilation efficiencies at the successive steps are like those in other terrestrial systems, no more than 0.00035 of the "plant" energy would reach the golden eagle by such a route. It is not just a detail that golden eagles feed primarily ( $>90 \%$ ) on herbivorous mammals (Newton 1979). Furthermore, in the Coachella Valley, which Polis studied, the 14-km distance from the center to the edge of the study area is small for a foraging eagle. Just because the energy pathway occurred does not mean that we should add to our estimate of the food chain length of the community or that we should alter our assessment of the logical boundaries of energy flow.

The second difficulty with the use of food webs is that competition is of necessity either ignored or assumed to exist (and to be of uniform strength) wherever consumers use a common resource (MacArthur 1958; Yodzis 1980; Diamond 1986). Each is clearly a serious oversimplification. Finally, taxonomic uncertainty has forced the pooling of biological species into "trophic species," especially at levels close to the producers. This amalgamation of biological species is tempting 
in the interest of simplification, but there is no logical place to stop short of becoming indistinguishable from trophic levels.

Weighing against these disadvantages are several positive aspects. Among these, food webs provide the theoretical possibility of obtaining detailed information about the flow of energy through a community, despite the fact that published webs (published for purposes other than their use in either analysis of energy flow or food web theory) are inaccurate. Thus, they permit partial analyses of community complexity in the search for pattern. Furthermore, food webs can be used to partition the influence of species that feed at more than one level, which thus provides a first step in reducing the complex food webs into trophic levels. The mean chain length calculations common in recent investigations of food web patterns (see, e.g., Cohen 1978; Pimm 1982; Briand and Cohen 1987) appear to us to be a step in this direction, though at present admittedly biased toward larger, more readily identified organisms. Clearly, weighting trophic linkages by energy flow as described by Levine (1980) would be preferable but for lack of data is rarely possible. What this approach does omit is the possibility that individual taxa may carry influence other than through their direct impact on energy flow. For example, nitrogen fixation is context-dependent; the importance of an $\mathrm{N}$ fixer to a community depends on whether other forms of $\mathrm{N}$ are present in limiting supply.

\section{Trophic Levels}

Different authors use the term trophic level in different senses. In particular, Cousins (1987) and Schoener (1989) describe multiple levels that approach food chains and food webs in their complexity. These differ from our definition of trophic level: a group of organisms acquiring a considerable majority of its energy from the adjacent level nearer the abiotic source. In principle, the way to define such a group is to measure all of the energy sources used by all organisms in an ecosystem, then to calculate trophic position (e.g., using Levine's [1980] Markovian chain method). A more practical way to identify (but not to define) this group is that the component organisms respond in a common way to significant perturbations to other levels (directly to adjacent levels or indirectly to more distant levels). Although the qualifier "considerable majority" in our definition leaves open the problem of omnivory, we believe that it is omnivory that limits the number of trophic levels. We suggest that omnivory becomes increasingly prevalent at higher trophic levels (there are, after all, more trophic levels below to consume) and that omnivores typically gain most of their energy from the lowest level on which they feed. These two observations taken together must truncate the number of trophic levels in any ecosystem. Indeed, Hastings and Conrad (1979) have suggested, using an evolutionarily stable strategy analysis, that food chains should be kept short by the evolution of a tendency in omnivores to feed on the energetically most rewarding (i.e., the lowest available) trophic level. They propose food quality differences between plant and animal tissue as a constraint on reduction in number of trophic levels. At the end of this article we suggest predator and prey morphologies as another. 
Classifying community structure into such broad categories as trophic levels may obscure the details of trophic complexity that are at least partly shown by food webs. This is especially true if there are many species feeding at two or more levels. We do not agree with Burns (1989) that the term trophic guild is necessary to denote what has been called trophic level in most of the literature or that the trophic level construct necessarily has the confusing properties he ascribes to it. We agree with him, however, that there are advantages in recognizing that individual species may feed at more than one trophic level (i.e., consume energy that has passed through a varying number of links in the food web). When this is the case, we see no reason why such species' influence cannot in principle be partitioned among trophic levels in the way that he and Strayer (1991) propose.

Cousins's (1987) provocative comments on the use of trophic levels raise a number of issues relevant to our discussion. He is bothered by the fact that individual species often cannot be identified with a single trophic level. In particular he suggests that a fourth trophic level is difficult to identify in most ecosystems because "taxonomic classification ceases to map approximately to trophic levels at this point" (Cousins 1987, p. 315). He goes on to suggest that higher orders of energy transfer nevertheless occur. The fact that a fourth (and in some cases higher) trophic level can readily be identified in pelagic systems complicates his argument, but, more to the point, it is precisely the fact that feeding at multiple trophic levels occurs that leads us to suggest that energy transfers above the third level in terrestrial systems are relatively unimportant. Cousins's criticism, like the food web analysis discussed above, overemphasizes rare interactions.

In terrestrial systems, a pattern of one species, one trophic level breaks down significantly only among the predators, which tend to be unselective about the level at which they feed. Predators do not, however, feed on foliage, sap, or bark. Virtually all omnivores in terrestrial communities consume seeds rather than leaves in addition to animals. Almost no seeds are involved in photosynthesis, and they do not constitute a major energy component of primary production. Thus, in an energy-flow-weighted analysis of trophic levels, we place terrestrial omnivores with carnivores. See, for example, the discussions of this in Slobodkin et al. (1967) and Hairston (1985). Seed eaters have been shown to have an effect on the composition of the plant community of the Chihuahan Desert shrub habitat (Brown and Heske 1990), but there is little evidence that they affect plant recruitment in forests. The extent to which omnivore and carnivore categories blend into one another is illustrated by the lists in Clements and Shelford (1939, p. 128). They give the proportions of seed and fruit versus insects for 33 species of North American birds. The values range from $93 \%$ seeds and $7 \%$ insects for the whitewinged crossbill to $40 \%$ seeds and fruit and $60 \%$ insects for the rose-breasted grosbeak. In a second table, a change from mostly seeds in winter to a large proportion of insects in summer is given for eight species. The range is from $100 \%$ seeds in winter and $21 \%$ insects in summer for the evening grosbeak to $100 \%$ seeds in winter and $100 \%$ insects in summer for the vesper sparrow. Many granivores (e.g., sparrows) switch to animal food when feeding their young, and we assign granivores, nectarivores, and pollen feeders to the carnivore trophic level. 
In contrast to terrestrial systems, energy acquisition at multiple levels occurs frequently in aquatic systems. For example, in pelagic communities, phagotrophic algae (Bird and Kalff 1986, 1987) and omnivorous zooplankton (Paffenhöfer and Knowles 1980; Sprules and Bowerman 1988) can be quite common. Nevertheless, the fact that whole trophic-level manipulations have discernible direct and indirect effects on other levels (see reviews in Carpenter 1988; Liebold 1989) shows that omnivory is not so prevalent that trophic levels are obscured. It would, of course, be more accurate if dietary compositions could be measured. Such measurements are relatively rare, but stable isotope methodology has in the past $15 \mathrm{yr}$ been used in a number of instances to evaluate the trophic position of organisms (see, e.g., Rau et al. 1983; Estep and Vigg 1985; Peterson and Fry 1987; Yoshioka et al. 1988), including those with uncertain diets (Peterson et al. 1985) or with uncertain contributions higher up the food chain (Fry 1986).

Using trophic levels as the primary subdivisions of communities condenses trophic complexity into units that are common to all ecosystems and permits direct comparisons of the trophic dynamics of different ecosystems in terms that are common to all. The logical boundaries between adjacent systems may perhaps be best evaluated in terms of trophic-level interactions that weight particular links in the food web for their energetic significance. Importantly, the use of trophic levels permits an analysis of the relative influence of competition and predation on the different whole levels. We argue that, especially for an overview such as ours, the use of trophic levels is the approach of choice.

\section{HOW MANY LEVELS?}

A first step in exploring the relationship between trophic structure and energetics is an assessment of the pattern and variability in the number of trophic levels within and between ecosystems. Some authors (e.g., Schoener 1989) have divided terrrestrial communities into as many as eight, when decomposers and detritivores are included. We maintain that for terrestrial ecosystems, it becomes arbitrary to use more than one level of herbivores and one of carnivores plus omnivores. The few species that prey preferentially on predators have negligible impacts on the carnivore trophic level as a whole. The great majority of predators either are specialized to take herbivores (parasitoids of caterpillars) or do not distinguish between the more numerous herbivores and other carnivores. We propose that the relatively small part of the carnivore level that specializes on other carnivores (e.g., hawks of the genera Accipiter and Falco, some members of which prey primarily on birds) represents an insignificant energy flux (see also Smith 1969). Predators of the forest floor feed indiscriminately on herbivores, detritivores, and smaller carnivores, as illustrated in table 1 , which classifies the food of salamanders from several populations in the Appalachians. Obviously, detritivores do not figure largely among the prey of predators that forage in the vegetation, but in this example they constitute a significant portion of the prey individuals.

In the pelagic zone of lakes, the situation is different. Omnivory is exhibited by a broad range of organisms, but a rigid size dependency of predation in pelagic 
TABLE 1

The Gut Contents of Two Species of Salamanders, Plethodon jordani and Plethodon glutinosus, Classified According to the Trophic Level of the Food Organisms

\begin{tabular}{|c|c|c|c|c|}
\hline \multirow{2}{*}{$\begin{array}{l}\text { Estimated Trophic } \\
\text { LeVEL of Prey }\end{array}$} & \multicolumn{3}{|c|}{$\begin{array}{l}\text { SPECIMENS FROM AN AREA OF SyMPATRY } \\
\text { (GREAT SMOKY MOUNTAINS) }\end{array}$} & \\
\hline & P. glutinosus & \multicolumn{2}{|c|}{ P. jordani } & \\
\hline \multirow{6}{*}{$\begin{array}{l}\text { Carnivore } \\
\text { Herbivore } \\
\text { Detritivore }\end{array}$} & 10.05 & \multirow{3}{*}{\multicolumn{2}{|c|}{$\begin{array}{l}14.67 \\
35.53 \\
49.37\end{array}$}} & \\
\hline & 29.58 & & & \\
\hline & 60.37 & & & \\
\hline & \multicolumn{4}{|c|}{ Specimens from Areas of Allopatry } \\
\hline & & \multicolumn{3}{|c|}{ P. JORDANI } \\
\hline & $\begin{array}{l}P . \text { GLUTINOSUS } \\
\text { (Ridge and Valley) }\end{array}$ & $\begin{array}{l}\text { Great Smoky } \\
\text { Mountains }\end{array}$ & $\begin{array}{l}\text { Grandfather } \\
\text { Mountain }\end{array}$ & $\begin{array}{l}\text { Nantahala } \\
\text { Mountains }\end{array}$ \\
\hline Carnivore & 20.61 & 12.46 & 38.18 & 51.26 \\
\hline Herbivore & 38.90 & 54.99 & 27.46 & 15.56 \\
\hline Detritivore & 40.50 & 32.55 & 34.36 & 33.18 \\
\hline
\end{tabular}

NoTE.-All locations are in the southern Appalachian Mountains. Numbers are unweighted means of percentage contributions by biomass, calculated from tables in Whitaker and Rubin (1971) and Powders and Tietjen (1974).

consumers, discussed later, maintains reasonably distinct trophic levels. In many lakes, predatory zooplankton may occupy an important intermediate link between grazing zooplankton and planktivorous fish. In addition, there is a moderately well-defined top predator level-the piscivorous fish, which specialize largely on other fish that consume principally invertebrates. Certainly there exist lakes with fewer trophic levels. In particular, small, highly seasonal, freshwater habitats (e.g., temporary ponds, small arctic-zone lakes) typically lack fish completely. However, by and large if we ignore for now decomposers and detritivores, most larger bodies of water are seen to contain four or five levels in the pelagic zone, whereas terrestrial communities contain only three.

This difference between the trophic structures of terrestrial and pelagic communities is corroborated by data presented by Briand and Cohen (1987). Using published food webs of 113 communities, they calculated mean chain length (roughly a surrogate for the number of trophic levels) for each. Although they did not view their results in this way, we calculated from the data they presented the mean chain lengths for all terrestrial communities as 2.6 (table 2). For pelagic communities, the value is significantly greater at $3.6(t=4.47, \mathrm{df}=52)$. Briand and Cohen ascribed the difference observed to one of dimensionality, concluding that three-dimensional habitats have longer chain lengths (more trophic levels) than do two-dimensional habitats. We suggest that dividing the data by dimensionality is arbitrary (they call forests three-dimensional and prairies two-dimensional) and that it obscures where the distinction lies. Indeed, the mean chain length for forest food webs in their data is only 2.6 and no different from those of other nonpelagic systems (tundra, 2.5; grasslands, 2.1; aquatic substrates, 2.6). The only potential exception, deserts and sand dunes, is discussed in a later section. 
TABLE 2

\begin{tabular}{|c|c|c|}
\hline Ecosystem & Mean Chain Length (SD) & $N$ \\
\hline \multicolumn{3}{|l|}{ Aquatic: } \\
\hline Pelagic & $3.6(.97)$ & 30 \\
\hline Substrates & $2.6(.59)$ & 45 \\
\hline Rivers & $2.6(.68)$ & 11 \\
\hline \multicolumn{3}{|l|}{ Terrestrial: } \\
\hline All & $2.6(.57)$ & 24 \\
\hline Forests & $2.6(.41)$ & 8 \\
\hline Grasslands & $2.1(.29)$ & 3 \\
\hline Tundra & $2.5(.67)$ & 9 \\
\hline Desert & $3.1(.55)$ & 3 \\
\hline Two dimensions & 2.4 & 40 \\
\hline Three dimensions & 3.2 & 28 \\
\hline
\end{tabular}

NoTE.-Categorization of habitat types made by the present authors according to information supplied by Briand and Cohen (1987).

Categorization of dimensionality follows Briand and Cohen (1987).

To us, the clear distinction lies between pelagic and nonpelagic communities. Moore et al. (1989) also criticized Briand and Cohen's (1987) concept of dimensionality. They go on to argue that some of the patterns Briand and Cohen identify result from the pooling of trophic levels in some food webs and the omission of trophic levels in other webs. In particular, they object to the pooling of phytoplankton and zooplankton into a single resource in near-shore marine habitats and rivers. Briand and Cohen (1989) have acknowledged that this policy may have biased their conclusions. To the extent that plankton play an important role in trophic transfer within a community, separating phytoplankton from zooplankton both adds a trophic level to the community and transfers it to our "pelagic" category.

In streams, as in the case of lakes, fish may or may not be present (Cooper 1988; Flecker 1992), or some streams may contain piscivores while others lack them (Bowlby and Roff 1986). Power (1990) recently identified another way in which the trophic structure of river communities may differ from that just described. The dominant grazer of benthic algae in the system she studied was a dipteran fly larva that weaves a retreat protecting it from predatory fish but not from damselfly nymphs. As a result, the predatory fish represent a fourth trophic level, above algae, fly larvae, and damselfly nymphs. In other streams and rivers the dominant grazers may be immature insects or snails that remain vulnerable to fish predation. In these, only three trophic levels exist. Clearly, trophic structure depends in this instance, and in others discussed below, on the particular characteristics of the organisms involved. Our goal here is to ask if general patterns overlie individual cases.

Interestingly, Pimm (1982), like Briand and Cohen, reports the number of trophic levels in terrestrial systems to be typically three while the number in aquatic pelagic systems to be typically four. We propose that this difference provides a basis for formulating and testing hypotheses concerning the controls on the num- 
ber of trophic levels, as well as concerning the effects of chain length on community structure.

\section{ENERGY TRANSFERS BETWEEN LEVELS}

In this section, we review and compare data on trophic transfer efficiencies in both terrestrial and freshwater pelagic ecosystems. Our review is not exhaustive, but the patterns we report are largely consistent between the studies cited. We point out where inconsistencies exist because these often represent places where specific community patterns appear to influence ecosystem processes.

For terrestrial systems, we obtained data from 20 studies (Gere, quoted in Balogh 1958, p. 129; Odum et al. 1962; Bray 1964; Witcamp and Crossley 1966; Dinesman 1967; Reichle and Crossley 1967; Wiegert and Evans 1967; Moulder and Reichle 1972; Reichle et al. 1975; Singh and Gupta 1977; Swift et al. 1979; Andrzejewska and Gyllenberg 1980; Coleman and Sasson 1980; Kajak 1980; Singh et al. 1980; Edwards et al. 1981; Slansky and Scriber 1985; Kurihara and Kikkawa 1986; Vogt et al. 1986; Martin 1987) and for freshwater pelagic systems from 11 studies (Alimov et al. 1972; Andronikova et al. 1972; Gak et al. 1972; Krogius et al. 1972; Moskalenko and Votinsev 1972; Pidgaiko et al. 1972; Sorokin 1972; Wetzel et al. 1972; Winberg et al. 1972; Hobbie 1980; Cole 1985). In presenting the results of our literature search, we must emphasize that the accuracy of the figures that we have found is almost never stated in the original articles. One indication of potential error comes from reports in several systems of consumption efficiencies exceeding $100 \%$ by substantial amounts.

\section{Terrestrial Ecosystems}

The bulk of organic matter in temperate forests (about 62\%) is in the form of dead organisms, nearly all plants. Accordingly, in our diagram of energy flow (fig. 1), this material occupies the largest compartment and a central position. In common with similar ecosystems, temperate forests have only a small fraction of net primary production (NPP) consumed by the herbivores, the best estimate being $2.6 \%-4.7 \%$. Even if we add the fall of leaves damaged by herbivores but not consumed by them, the addition amounts to only $1 \%-2 \%$ of the total litterfall (Risley and Crossley 1988). This observation had been made qualitatively for many years (see, e.g., Galoux 1953; Hairston et al. 1960). Two-thirds of what is eaten, however, is not digested and joins the dead organic matter on the forest floor. Thus, less than $1 \%$ of NPP is actually assimilated by the next trophic level. Nearly all of the biomass produced by the herbivores is consumed by the carnivores, the estimates ranging from $75 \%$ to $100 \%$. Moreover, the carnivores assimilate a comparatively large fraction of what they eat- $56 \%$. Thus, consistent with Kozlovsky's (1968) observation, consumption efficiency increases with trophic level, and clearly, as others have noted (e.g., Kozlovsky 1968; Whittaker 1975), the ecosystem is not governed by some principle that regulates a constant proportion of energy reaching successive trophic levels.

The energy bound in dead organic matter flows through the ecosystem by entirely different allocations. A small fraction (about 15\%) is leached or undergoes 


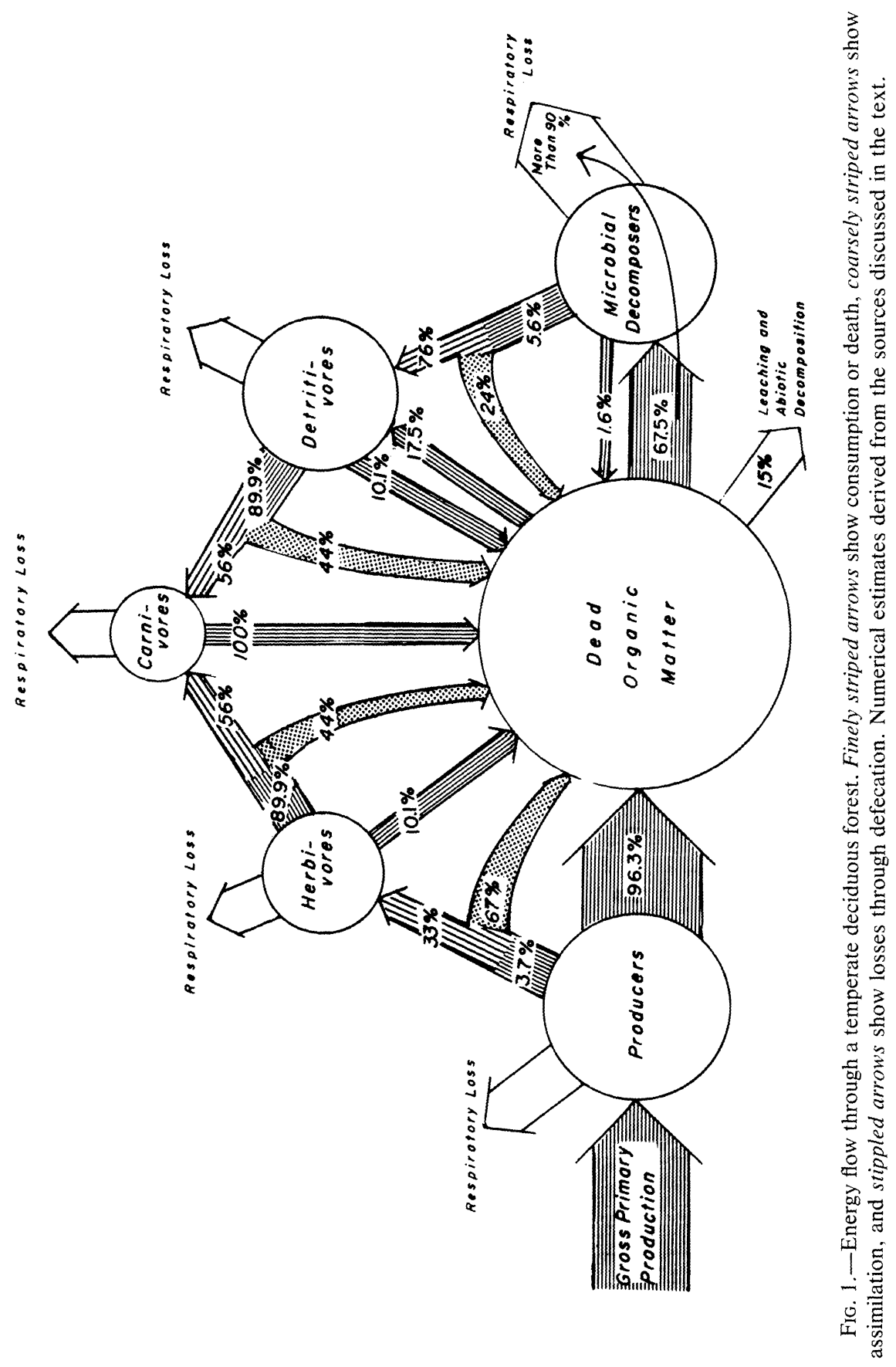


abiotic decomposition. Kurihara and Kikkawa (1986) give a range of estimates from $8 \%$ to $23 \%$ for dead leaves of different species of trees. Detritivore consumption was estimated as follows: Kurihara and Kikkawa estimate that millipedes consume $1.7 \%-10 \%$ of the annual litterfall. From respiration data in Reichle et al. (1975) it can be calculated that millipedes account for $32.9 \%$ of detritivore consumption. Thus, consumption by detritivores is $5.2 \%-30.4 \%$ of annual litterfall. The digestibility of this averages $32 \%$, with a range from $4 \%$ to $82 \%$ (Martin 1987). They can thus digest directly $1.7 \%-9.7 \%$ of the litter, or $2.7-15.6$ $\mathrm{g} \mathrm{C} \cdot \mathrm{m}^{-2} \cdot \mathrm{yr}^{-1}$, in addition to the microflora (bacteria and fungi) ingested. The microflora, which amount to $11.33 \mathrm{~g} \mathrm{C} \cdot \mathrm{m}^{-2}$, are $71 \%-82 \%$ digestible, according to Martin, and thus account for an assimilation of $8-9.3 \mathrm{~g} \mathrm{C} \cdot \mathrm{m}^{-2} \cdot \mathrm{yr}^{-1}$. The total assimilated by the detritivores is thus $10.7-24.9 \mathrm{~g} \mathrm{C} \cdot \mathrm{m}^{-2} \cdot \mathrm{yr}^{-1}$. The microflora are extraordinarily active metabolically, and their respiration accounts for more than $90 \%$ of what is available to them (Reichle et al. 1975). This feature leads us to make a separate trophic level of the microflora. They make up a large fraction of the assimilable food of the detritivores, which obtain at least five or six times as large a fraction of the net primary production as do the herbivores. As the herbivores (consumers of leaves, sap, and wood) consume only $2.6 \%-5 \%$ of the net primary production (Reichle et al. 1973; Whittaker 1975), the litter makes up the remainder, amounting to $161-229 \mathrm{~g} \mathrm{C} \cdot \mathrm{m}^{-2}$. The herbivores thus consume $4.3-12 \mathrm{~g} \mathrm{C} \cdot \mathrm{m}^{-2} \cdot \mathrm{yr}^{-1}$, of which $33 \%-40 \%$ is digestible (Martin 1987). This means that they assimilate $1.42-4.8 \mathrm{~g} \mathrm{C} \cdot \mathrm{m}^{-2} \cdot \mathrm{yr}^{-1}$ or $1 / 7.5-1 / 5.2$ that of the detritivores. This calculation does not take into account the turnover of small roots in deciduous forests, with a large proportion decomposing each year. Respiration from the decomposition of dead small roots is nearly twice that from litter plus soil organic matter (Edwards et al. 1981). As a result of the large respiratory loss at the microflora level, detritivores normally contain only 1.7-6.1 times the biomass of the herbivores (Edwards et al. 1970), even though more than $95 \%$ of NPP passes to the detritus. Thus, the efficiency of energy transfer from primary producers to consumers differs markedly depending on whether the pathway is from living primary producers to herbivores or from dead primary producers through decomposers to detritivores. The physiology of the microflora, like the populational effect of the carnivores on the herbivores, is the determining factor for the decomposition side of the forest ecosystem.

Apparently, the carnivores are as effective against the detritivores as they are against the herbivores, although the hypothesis needs to be tested experimentally. Spiders alone consume $65.6 \%$ of the average standing crop of their detritivore prey annually (Moulder and Reichle 1972), and other forest floor predators must consume substantial amounts as well. Given that woodland spiders have been shown to be food limited (Wise 1975, 1979, 1981), it seems highly likely that their predation seriously impacts prey density.

Comparable studies in other terrestrial ecosystems have yielded similar data (table 3). It is interesting to compare the fate of litter in forests where the consumption of NPP by herbivores ranges from only $2.6 \%$ to $7 \%$, specifically in temperate deciduous and tropical forests. The range of values for both kinds of forest is considerable, but in all cases the relative values within forests are similar. Values for NPP in temperate forests (in $\mathrm{t} \cdot \mathrm{ha}^{-1} \cdot \mathrm{yr}^{-1}$ ) are 9 for oak 
TABILE 3

Some Trophic Structure Characteristics and Secondary Production Estimates FROM VARIOUS TERRESTRIAL ECOSYSTEMS

\begin{tabular}{lcccc}
\hline \hline & $\begin{array}{c}\text { Mean NPP } \\
\left(\mathrm{t} \cdot \mathrm{ha}^{-1} \cdot \mathrm{yr}^{-1}\right)\end{array}$ & $\begin{array}{c}\text { Animal Consumption } \\
(\% \text { NPP })\end{array}$ & $\begin{array}{c}\text { Litter } \\
\left(\mathrm{t} \cdot \mathrm{ha}^{-1}\right)\end{array}$ & $\begin{array}{c}\text { Litter Turnover } \\
\text { Time } \\
(\mathrm{yr})\end{array}$ \\
\hline Temperate deciduous forest & 11.5 & $2.6-5$ & 15 & 4 \\
Temperate grassland & 7.5 & 10.7 & 5 & 2 \\
Boreal forest & 7.5 & 4 & 35 & 14 \\
Tundra & 1.5 & 3 & 44 & 100 \\
Savanna & 9.5 & 15 & 3 & 1 \\
Tropical forest & 30 & 7 & 5 & $.12-.5$ \\
\hline
\end{tabular}

Note._Values from Whittaker (1975) and Swift et al. (1979).

forest and 13 for beech forest (Rodin and Basilevic 1968), 10 for "warm temperate mixed forest"' (Lieth 1975), and 11.5 (Swift et al. 1979) and 6-25 (Whittaker 1975) for temperate deciduous forest. For tropical rain forests, the values are 10-35 (Lieth 1975; Whittaker 1975), 32.5 (Rodin and Basilevic 1986), and 30 (Swift et al. 1979). Thus, most tropical forests are more productive. For the litterfall, the values for temperate forests are 6.5 (oak) and 9 (beech) (Rodin and Basilevic 1986) and 11.5 (Swift et al.). For tropical forests, the values are 25 (Rodin and Basilevic) and 30 (Swift et al.). These approximately match NPP. The great contrast is in the standing amount of litter: 15 for all temperate forests for which we find data and 2 (Rodin and Basilevic) and 5 (Swift et al.) for tropical forests. Kurihara and Kikkawa (1986) give the ratio of standing crop of forest floor litter to litterfall as 5-9 for temperate forests and 0.1 for tropical rain forests. Indeed, one of the most striking features of a tropical rain forest for the ecologist is the near absence of litter. Accustomed to a positive relationship between the amount of litter and leaf mould and the general "lushness" of temperate forests, we are amazed to be able to kick a few dead leaves and see laterite. Decomposition in the tropics is so rapid that the nutrients, and hence the total carbon, are nearly all in the trees, whereas in temperate forests the amount in trees is less than half of the total. In the grassland ecosystems, the major differences from forests lie in the proportion of production in all trophic levels that is underground (fig. 2). Otherwise, the flow of energy is much like that in forests (Coupland and Van Dyne 1979; Swift et al. 1979). It is true that herbivores in grasslands take a somewhat larger fraction of NPP, but the proportion is still quite small. The rest of the flow is little changed by the difference.

Pristine grasslands, with complete faunas undisturbed by modern man, are virtually unknown. The closest approach is the Serengeti, which is a tropical savanna-that is, with scattered trees over much of its area. For much original data, see Sinclair and Norton-Griffiths (1979); for a good general description, see Ehrlich and Roughgarden (1987). Like the North American long-grass prairie, most of the Serengeti is maintained by fire, as shown in table 4. Only in the short-grass part does fire consume less than $50 \%$ of NPP. The migratory habit of the bulk of the herbivore biomass makes interpretation difficult, but they clearly 


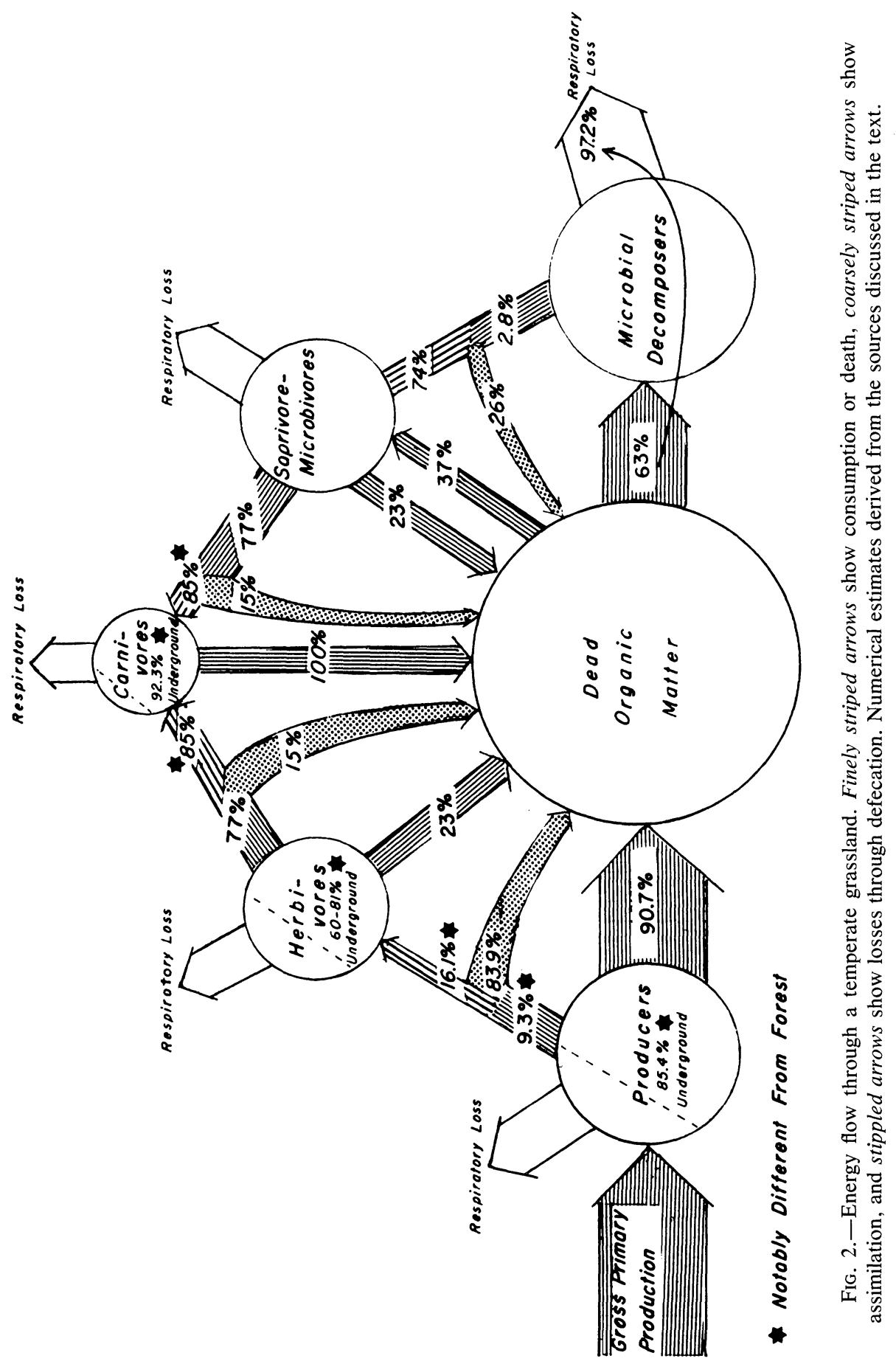


TABLE 4

The Fate of Net Primary Production in the Serengeti

\begin{tabular}{llcc}
\hline \hline & \multicolumn{3}{c}{ HaBITAT TYPE } \\
\cline { 2 - 4 } & Kopjes & Long Grass & Short Grass \\
\hline \% Net primary production consumed by: & & & \\
Herbivores & 14.4 & 27.6 & 38.2 \\
Detritivores & 28.2 & 19.2 & 49.5 \\
Fire & 57.4 & 53.3 & 12.5 \\
\hline
\end{tabular}

Note. - Values from Sinclair (1975). Note greater herbivore consumption than the average figure for savannas in table 3 . The percentage of herbivore production consumed by carnivores was $35.0 \%$; by scavengers, $65.0 \%$.

consume a much larger fraction of NPP than they do in any other terrestrial ecosystem. Nevertheless, Sinclair (1985) has recently concluded that the large herbivores are predator controlled.

\section{Freshwater Ecosystems}

In contrast to terrestrial ecosystems, grazers of the pelagic open-water zone of lakes and ponds show substantially greater consumption efficiencies, with a mean of $32.8 \%$ of NPP consumed by grazing zooplankton (fig. 3). Riemann et al. (1986) placed the value as high as $70 \%$. For grazers eaten by either predatory zooplankton or planktivorous fish, a mean of $90 \%$ of production is consumed. Finally, $74 \%$ of planktivorous fish production is consumed by piscivores. These values were obtained from studies of 12 north temperate zone lakes and one arctic pond (references given above). Net primary production values ranged in these studies between $0.75 \mathrm{~g} \mathrm{C} \cdot \mathrm{m}^{-2} \cdot \mathrm{yr}^{-1}$ and $156 \mathrm{~g} \mathrm{C} \cdot \mathrm{m}^{-2} \cdot \mathrm{yr}^{-1}$. Assimilation efficiencies calculated from data provided in 11 of the studies show a remarkable consistency ranging between $75 \%$ and $82 \%$ regardless of trophic level (except bacterioplankton for which ingestion and assimilation are not distinct). It is unclear, however, whether this consistency results from a genuine similarity in pelagic processes or the repeated application of a predetermined value. In any event, consumption efficiency in these systems does not show as distinct an increase with trophic level as was found in the terrestrial data. Indeed, if anything, there appears to be a peak in transfer efficiency at the intermediate (herbivore to primary carnivore) level.

The fate of detritus in the pelagic zone of lakes and ponds is quite different from that in terrestrial systems. Water is much more viscous than air, and dead phytoplankton cells are small and only slightly more dense than water; thus, detritus settles to sediments comparatively slowly, which allows time for much of it to be colonized by bacteria, consumed by grazers, or both before reaching the bottom. The fecal pellets of copepods in general sink more quickly than do living or dead algae or the loose feces of other zooplankton (e.g., Daphnia). Thus, whether detritus reaches the sediments depends on the type of grazer present, the depth of the water column, and the extent of vertical mixing. Furthermore, 


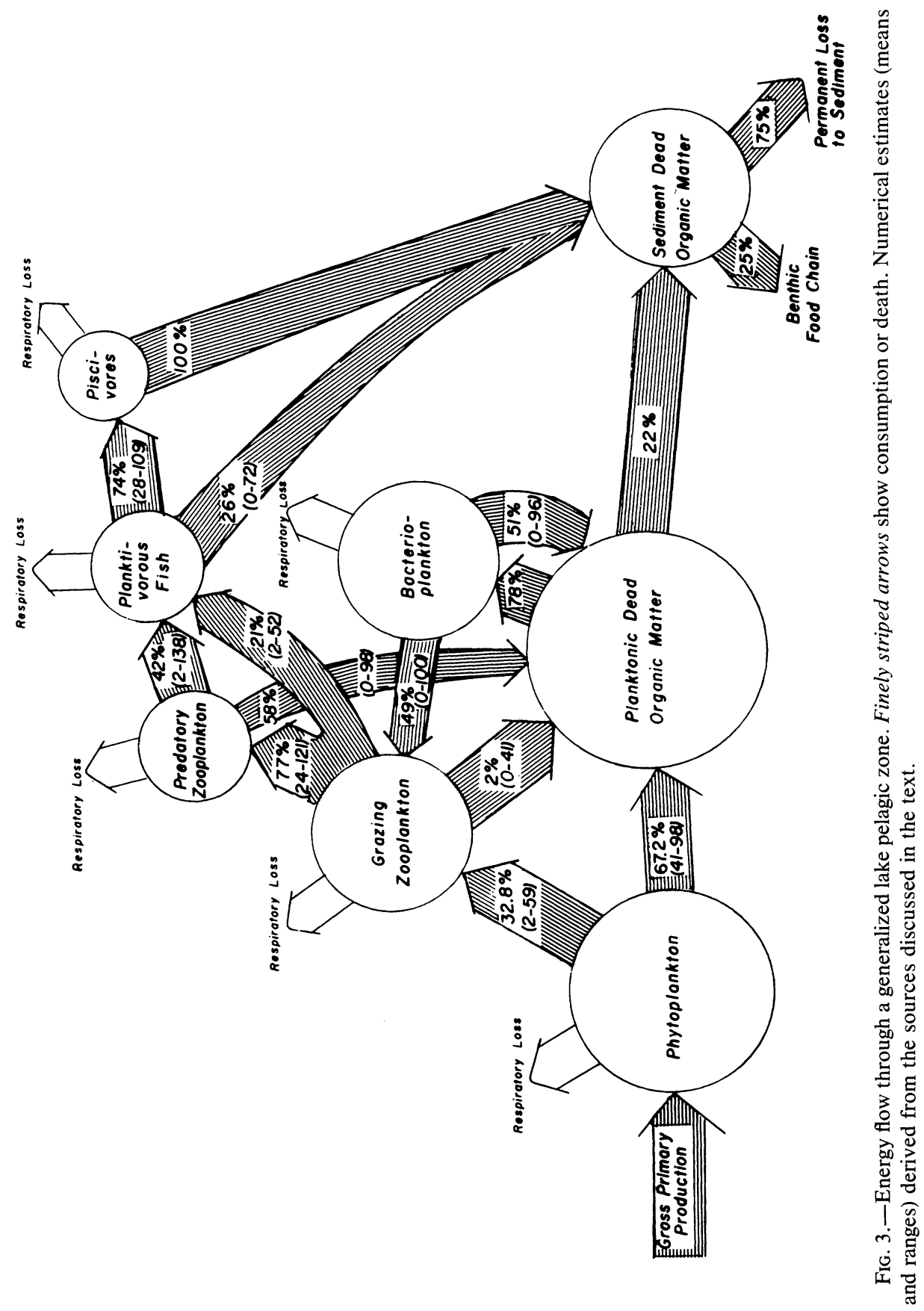


a substantial amount of dead organic matter is present in the water as dissolved organic carbon, at least some of which is used by bacteria (Wetzel et al. 1972; Wetzel 1984; Riemann et al. 1986). These processes constitute the "microbial loop," which has been highlighted beginning in the European literature in the 1960s (e.g., Hillbricht-Illkowska et al. 1966; Saunders 1969; Overbeck 1972) and is attracting much current attention (see, e.g., Stockner and Porter 1987; Porter et al. 1988; Sherr and Sherr 1991). This loop clearly contrasts with the terrestrial environment in which comparatively large pieces of detritus fall quickly through the air to the ground, away from the activity of herbivores. Even though the estimates may be imprecise, in many of the studies summarized in figure 3 it appears that in lakes perhaps $60 \%$ of the NPP is consumed in the microbial loop, never reaching the sediments. This number is consistent with Forsberg's (1985) and Riemann and Søndergaard's (1986) estimates that bacterioplankton production can reach $70 \%-85 \%$ of phytoplankton production. The fraction of the pelagic detritus that is returned to the grazing trophic level probably depends on the taxa of zooplankton present. Some groups (e.g., cladocerans) apparently consume detritus and bacteria, whereas others (e.g., calanoid copepods) do not (DeMott 1988; Pace et al. 1990). Ducklow et al. (1986) found for a coastal marine pelagic system that very little energy made its way from bacterial production to larger grazing zooplankton. Because the latter group in marine habitats is typically dominated by copepods rather than cladocerans (a distinction apparently dating from the evolution of suction-feeding planktivorous fishes during the Mesozoic; Kerfoot and Lynch 1987), the low return of energy to the marine food chain via the microbial loop may reflect the grazing capabilities of the macrozooplankton. Freshwater systems, in contrast, may be dominated either by copepods or cladocerans and thus may be expected to vary in the importance of the microbial loop (Pace et al. 1990). For seven of the 12 lakes summarized in figure 3, data are available on the seasonal average composition of the zooplankton. There is a positive relationship between the logarithm of the ratio of nonpredatory cladocerans to copepods and the fraction of bacterioplankton production that is consumed by grazing zooplankton (fig. 4) (Epishura bicalensis is included here with cladocerans because this copepod, endemic to Lake Baikal, is known to consume bacteria [Moskalenko and Votinsev 1972]). An important role for phagotrophic protists as an intermediate link between bacteria and zooplankton has been advocated by Sherr and Sherr $(1988,1991)$, but the amount of energy that returns to the grazing food chain is still questionable (Fenchel 1988).

The portion of NPP actually reaching the bottom amounts to about $15 \%$, in striking contrast with the more than $95 \%$ NPP reaching the forest floor (fig. 1). Once on the lake bottom, however, only $25 \%$ is consumed (Wetzel et al. 1972) either by detritivores or microbes. The remaining about $12 \%$ of NPP accumulates annually in the sediment. That being the case, the amount of standing biomass of detritus in a lake, including sediments, would depend on the age of the lake. This contrasts markedly with the total organic carbon on a mature forest floor, which remains constant on an annual average basis. This difference in accumulation of dead organic matter probably results from a greater tendency for anaerobic decomposition in lake sediments than in forest soils. Canfield (1989) found lower 


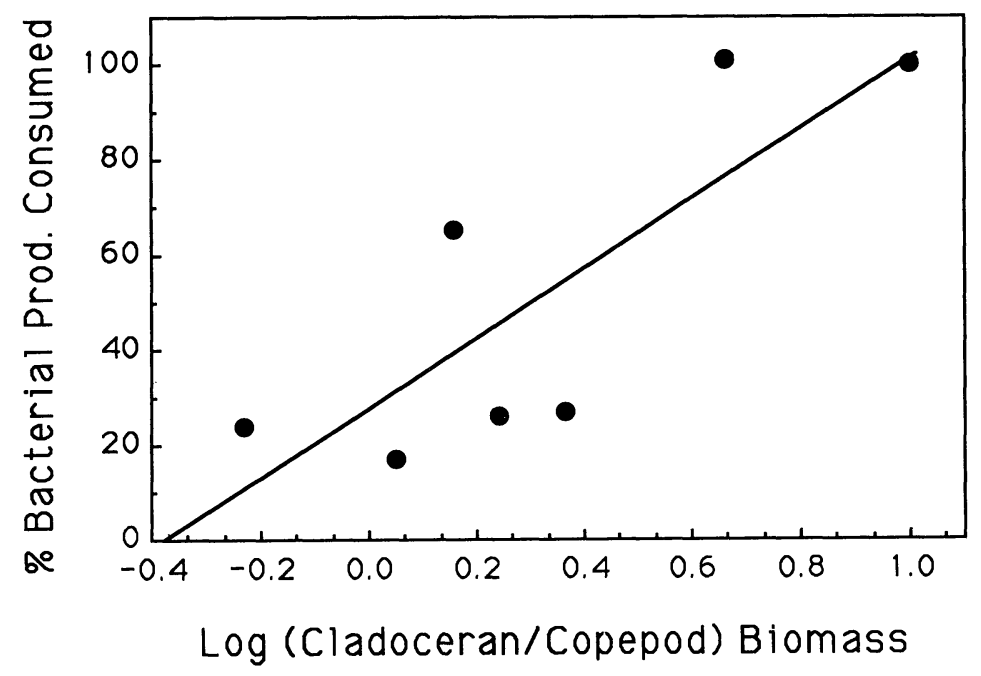

FIG. 4.-The fraction of bacterioplankton consumed by grazing zooplankton in seven pelagic lake communities (see text) as a function of the relative biomass of nonselective cladoceran and selective copepod consumers $\left(r^{2}=0.66, P=.027\right)$.

decomposition efficiencies in marine sediments underlying anaerobic waters than those underlying aerobic waters.

When entire lake ecosystems are considered, the role of littoral vegetation and allochthonous inputs can lead energy dynamics to be much more similar to terrestrial systems. Very little of the NPP by macrophytes is consumed by herbivores (Wetzel 1983), with most of the production that is consumed going to bacteria. This result could conceivably represent an indirect route to planktonic grazing zooplankton, but Wetzel et al. (1972) did not find this to be the case in Lawrence Lake, and Wetzel (1990b) concludes virtually none of freshwater littoral zone production makes its way into the pelagic food chain. In relatively small bodies of water with extensive shorelines, these littoral zone dynamics can dominate (see, e.g., Wetzel et al. 1972). At higher, more mobile trophic levels, piscine consumers in small lakes may move between the pelagic and the littoral zones (Werner et al. 1983; Mittelbach 1986), which makes their relative trophic impacts in these distinct habitats difficult to quantify (Lodge et al. 1988). The situation in marine estuarine systems is in some ways similar to lakes. Although carbon is exported from marshes into near-shore waters via tidal flushing, little or none of the energy supplement is reflected in fish production (Nixon 1980). Once again trophic efficiencies depend critically on the nature of the system (pelagic or littoral) under study.

\section{EFFICIENCIES OF ENERGY TRANSFER ARE SYSTEM-DEPENDENT}

Do the data just summarized give us insight into the relationship between energetics and trophic structure? Pelagic systems have one or two more trophic 
levels on the average than do terrestrial ones, yet this result cannot be explained by any general tendency for them to be of higher productivity. In fact, just the opposite is true. On a global scale, lakes $\left(0.10-1.5 \mathrm{~kg} \mathrm{C} \cdot \mathrm{m}^{-2} \cdot \mathrm{yr}^{-1}\right)$ and the oceans $\left(0.01-1.0 \mathrm{~kg} \mathrm{C} \cdot \mathrm{m}^{-2} \cdot \mathrm{yr}^{-1}\right)$ fall at the low end of areal primary productivity compared to forests $\left(0.4-3.5 \mathrm{~kg} \mathrm{C} \cdot \mathrm{m}^{-2} \cdot \mathrm{yr}^{-1}\right)$ and savannahs or grasslands $\left(0.2-2.0 \mathrm{~kg} \mathrm{C} \cdot \mathrm{m}^{-2} \cdot \mathrm{yr}^{-1}\right.$ ) (see reviews by Whittaker and Likens 1973; Whittaker 1975). Similarly, shallow coastal marine communities have higher productivities on the average $\left(0.2-1.0 \mathrm{~kg} \mathrm{C} \cdot \mathrm{m}^{-2} \cdot \mathrm{yr}^{-1}\right)$ than do those of the open ocean (0.01-0.4 $\left.\mathrm{kg} \mathrm{C} \cdot \mathrm{m}^{-2} \cdot \mathrm{yr}^{-1}\right)$, but, as Ryther (1969) and Landry (1977) have pointed out, coastal systems have shorter food chains than do oceanic ones.

This is not to say that variation in primary productivity has no effect on higher trophic levels. Clear positive relationships are well-known between primary and secondary productivity in both pelagic and terrestrial systems. For example, drawing on data from many of the same studies used to construct figure 3, Brylinsky and Mann (1973) and Brylinsky (1980) showed significantly higher productivity of both herbivorous zooplankton and predatory zooplankton in the presence of higher primary productivity. Oglesby (1977) documented higher fishery yields in lakes with higher primary production, and Nixon (1982) found a similarly positive relationship for marine environments. In a survey of terrestrial communities, McNaughton et al. $(1989,1992)$ found that herbivore productivity is positively correlated with net primary productivity. Furthermore, a pattern depicted in figures 1 and 2 appears to be general: herbivore consumption rate is higher in grasslands than in forests at any given level of primary productivity, a result McNaughton et al. (1989) ascribe to domination of the herbivore trophic level by vertebrates in grasslands and by invertebrates in forests.

There are even significant relationships between the values of the physical and chemical parameters known to affect primary production and the performance of higher trophic levels. Pace (1986) found that lakes with higher water-column phosphorus concentrations had higher zooplankton biomass. In a terrestrial community, Coe et al. (1976) showed that the productivity of large grazers in African game parks was a positive function of annual rainfall. Nevertheless, despite these relationships and in contrast to both the early expectations of Hutchinson (1959) and Slobodkin (1962) and principles more recently espoused by others (e.g., Fretwell 1977, 1987; Oksanen et al. 1981), the number of trophic levels does not appear to increase as a function of the amount of energy passing up the food chain. The latter authors are in fundamental agreement with HSS about alternation of trophic control of trophic levels, but one feature of their development is a proposal that the number of levels increases with increasing primary productivity. Although this may be the case theoretically, we find it difficult to identify any natural systems that have less than three trophic levels for reasons of limited production. Only extreme physical features (e.g., low island area, anoxia in lakes) seem to produce one-level or two-level communities.

What does determine the number of trophic levels in a community or ecosystem? We have already stated our agreement with Hastings and Conrad (1979) that omnivory truncates food chain length. We focus here on the contrast between terrestrial and pelagic communities to consider this problem. In particular, we 
consider which hypotheses can account for our observations that pelagic communities tend to have four or five levels, whereas terrestrial (and other nonpelagic) communities tend to have three (ignoring in both cases the decomposers and detritivores, which are present in both kinds of systems).

One hypothesis is that the magnitude of the microbial loop in open water is sufficient to support an additional trophic level above the primary carnivores (planktivores). Enough detritus remains suspended in the water column, the argument goes, for the decomposer microbes to provide sufficient extra food for filter-feeding herbivore production to support a large enough biomass of planktivorous fish to maintain the piscivores. This is closely related to the original tenet of Hutchinson (1959) and Slobodkin (1962) that the number of trophic levels depends on the supply of energy. Certainly, available energy must set some upper limit to the number of trophic levels that any area can support, as must the amount of space available in which the top trophic level can forage (Schoener 1989). Nevertheless, both Pimm (1982) and Briand and Cohen (1987) in their general reviews were unable to find any statistical relationship between NPP and the number of trophic levels in a broad range of community types. When lakes ranging between $25 \mathrm{mg} \mathrm{C} \cdot \mathrm{m}^{-2} \cdot \mathrm{d}^{-1}$ and $1,240 \mathrm{mg} \mathrm{C} \cdot \mathrm{m}^{-2} \cdot \mathrm{d}^{-1} \mathrm{NPP}$ all have four trophic levels (Pimm 1982), a threefold boost (maximum) in trophic transfer accruing from the microbial loop looks relatively minor.

The hypothesis favored by Pimm and Lawton (1977) and Pimm (1982) is that dynamical stability places constraints on food chain length. In particular, their argument is that longer chains take longer to return to equilibrium after perturbation. There are a number of simplifying assumptions in the approach used by those authors that lead us, and have led others (e.g., Saunders 1978; Hastings 1988), to question the relevance of their conclusions, including assumptions that local stability is an appropriate measure of persistence, that increased return times increase the likelihood of extinction, that there are single or few species per trophic level, that intraspecific density dependence occurs only at the lowest trophic level, and that demographic or spatial complexity need not be considered. For the comparison between pelagic and terrestrial systems, no reason occurs to us why pelagic communities should be less susceptible to perturbation. Wetzel (1984) suggested that the large reservoir of detritus present in lakes might provide a base resource that would "impart metabolic stability" to these systems. $\mathrm{He}$ observed, however, that very little of either the particulate or dissolved organic carbon that makes up the detrital pool in fresh water actually enters the consumer food chain. Indeed, in planktonic systems, extreme fluctuations in population sizes of both producers and consumers are quite typical.

We propose the following hypothesis to account for the difference in the number of trophic levels between most pelagic systems and most terrestrial ones. In planktonic communities, the primary producers are unable to hold space, and they are selected to be small (for suspension in the water column, enhanced nutrient uptake, and for rapid reproduction) (see also Smith 1975; Lewis 1976; Reynolds 1984). The herbivores are generally small to feed better on the unicellular algae. Under such conditions, a four-level system is likely, because the zooplanktivorous fish provide the only suitable prey for larger fish. Ryther (1969) proposed 
size-dependent consumption as an explanation for difference in food chain lengths in the ocean, where phytoplankton cell size is greatest near shore waters where food chains are shortest. This dynamic is enhanced by the morphological constraints placed on swimming organisms in the viscous aquatic habitat. Predators in the pelagic zone, even when they derive from quite distinct phylogenetic backgrounds (e.g., killer whales, tuna, dipteran larvae, arrow worms), nearly uniformly have a fusiform shape and capture their prey by the sole use of their mouths. Their appendages are typically reduced to fins for efficient locomotion in that habitat. As a result, these animals experience strong gape limitation in the prey they can capture. That is, the maximum prey size captured and consumed is limited to the width of the predator's mouth (Zaret 1980). The gape limitation constraint reduces the amount of feeding at multiple trophic levels high in the food chain, as compared with communities in other habitats. A related idea is Cousins's (1987) suggestion that the number of trophic levels is dependent on the average ratio of predator size to prey size. We suggest that this ratio is likely to be much larger on the average in pelagic systems than in terrestrial systems, where indeed it is often less than one (e.g., insects feeding on trees, pack-hunting carnivores).

The competition of terrestrial producers for resources results in their competing for space. They are abundant enough to compete because the herbivores in a three-trophic level system consume only a very small fraction of the NPP. Competition for space selects for large size and longevity. This large size in turn means that herbivores are not constrained to be any particular size, and in fact they span the complete range of sizes for terrestrial animals. Carnivores generally feed indiscriminately on other carnivores as well as on the more numerous herbivores, and there is no stratification by size among them.

These hypotheses should have applicability to systems beyond those we explicitly consider here, though perhaps in combinations different from forests, prairies, or pelagia. For example, in the littoral zone of lakes, rooted macrophytes, which account for two-thirds of NPP (Wetzel et al. 1972), occupy space like their terrestrial counterparts, while the consumers are gape limited as in the pelagic zone. Do three or four trophic levels prevail? The answer is typically four, again with large piscivorous fish at the top, which suggests that the constraints of the fluid medium are more significant than resource dynamics of the producers. One may ask, then, why with four levels macrophyte beds persist. A possible answer may again lie in the physical dictates of the environment. Unlike the predominance of the fusiform body shape in truly pelagic fishes, the primary carnivores in the littoral of lakes are typically deep-bodied fish adapted for hovering and high maneuverability (Greenway 1965; Keast and Webb 1966). As noted below, this body form is particularly invulnerable to piscivory (Hambright et al. 1991) and may dilute effects of the top trophic level further down the food chain.

Gape limitation may occur in some terrestrial food chains dominated at the top by lizards or snakes (De Marco et al. 1985), which has been demonstrated to influence trophic structure in the way proposed for the pelagic zone (Spiller and Schoener 1990). In the American Southwest, there is little experimental evidence that the insectivorous lizards compete interspecifically (Hairston 1989). These 
TABLE 5

Consumption Efficiencies (\%) for Temperate Terrestrial and Freshwater Pelagic Communities (SE)

\begin{tabular}{lccc}
\hline \hline & \multicolumn{2}{c}{ Terrestrial } & \\
\cline { 2 - 3 } & Deciduous Forest & $\begin{array}{c}\text { Grassland } \\
\text { (Aboveground) }\end{array}$ & PelaGic \\
\hline Producers $\rightarrow$ herbivores & $3.7(.79)$ & $9.3(3.12)$ & \\
Herbivores $\rightarrow$ first-degree predators & $89.9(4.96)$ & $77.0(2.3)$ & $24.5(4.49)$ \\
Primary predators $\rightarrow$ secondary predators & $\ldots$ & $\ldots$ & \\
\hline
\end{tabular}

communities could provide a (further) test for the gape limitation hypothesis, because the lizard-eating predators are larger lizards, snakes, and the roadrunner, Geococcyx californianus, all of which are gape limited. The fact that mean chain length for the three desert and sand-dune food webs reported by Briand and Cohen (1987) (table 2) approaches that of pelagic systems is at least suggestive. Care would have to be taken, however, to define what assemblage of species was under investigation. Experiments in deserts appear to reveal three groups of organisms that have few if any intergroup interactions: the perennial plants and their herbivores and predators, the annual plants and the granivores that depend on their seeds, and the insectivores and their prey and predators (Hairston 1989).

If productivity and trophic transfer efficiencies do not have a demonstrable effect on the number of trophic levels in a community, is the converse true? Does the number of trophic levels influence productivity or trophic efficiency? If terrestrial communities typically have three trophic levels and pelagic lake communities typically have four, then according to the HSS hypothesis we would expect the fraction of primary production consumed by herbivores to differ between the two systems because herbivores in terrestrial communities should be limited by predation, whereas those in pelagic should be food limited. Consumption efficiency should then be lower in terrestrial than in pelagic systems. For the studies summarized in figures $1-3$, this is distinctly the case (table 5), with an average of over $32 \%$ of primary production consumed by zooplankton in lakes but only between $4 \%$ and $9 \%$ of terrestrial aboveground primary production consumed by herbivores.

At the next trophic transfer (herbivores to primary carnivores), we expect the reverse to be the case: food limitation in terrestrial and predator limitation in pelagic communities. Here, however, the analysis of pelagic systems becomes complicated by the presence of predatory invertebrates (fig. 3). Two interpretations are possible. If we ask what fraction of grazing zooplankton production is ultimately consumed by planktivorous fish, then consumption efficiencies are consistent with the HSS prediction: only some $24 \%$ of grazer production is consumed by planktivorous fish in lakes as compared with between $77 \%$ and $90 \%$ of aboveground herbivore production consumed by predators in terrestrial communities. On the other hand, if we ask what fraction of grazing zooplankton production is consumed by predators of whatever type (either invertebrates or fish), 
then the value is on the average $90 \%$. The difference lies in the inefficiency of energy transfer from predatory invertebrates to zooplanktivorous fish.

Finally, if in a four-level pelagic system zooplanktivorous fish are limited by piscivores, then a substantial fraction of the production by the former must be consumed by the latter, which is the case (table 5). A small amount of production by primary predators is consumed by other predators in terrestrial systems. We were unable to assign an efficiency value to this, but our prediction is that it should be low. For example, predators compose a relatively small fraction of the total diets of top carnivores in several terrestrial systems. For birds of prey feeding in eastern deciduous forests, $64.2 \%$ of their diet is on the average composed of herbivores, $13.1 \%$ of omnivores, and $23.1 \%$ of carnivores (data taken from Bent 1937-1938). A different approach is to tally the number of families or subfamilies of predaceous or parasitoid insects that attack herbivores, omnivores, or carnivores. Comstock (1948) gives information on 132 such taxa. For 86 of them, one prey type is specified (e.g., caterpillar, wood-boring beetle, spider, wasp, ant); of these, $67(77.9 \%)$ are herbivores, 7 (8.1\%) are omnivores, and 12 (13.9\%) are predators. For 17 taxa (12.9\% of the 132), at least two categories of prey were listed (e.g., both herbivores and predators), and 29 taxa were simply described as "predaceous." It seems reasonable to allocate the prey of these last two categories in the same proportions as those that are definite. Overall, the food of predators and parasitoids is taken in rough proportion to the availability of herbivores and carnivores as potential prey. As one example, the standing crop biomass of canopy consumers in the deciduous forest at Oak Ridge consists of $79 \%$ herbivores and $21 \%$ predators (Edwards et al. 1981).

Within particular communities, evidence for control of ecological energetics by trophic structure comes from both comparative data and experimental studies. For lakes and ponds, recent literature has stressed the impact of the consumer trophic levels (see, e.g., Carpenter et al. 1987; Bendorf 1988; Carpenter 1988; Carpenter and Kitchell 1988). For the group of aquatic studies summarized in figure 3 , there is substantial variation in herbivore consumption efficiency. Is some of this variation explained by differences in trophic structure, for example, differences in the relative importance of the predatory invertebrates in the grazing food chain? For the six lakes for which the required data are available, consumption of primary production by grazing zooplankton ranged between $12 \%$ and $59 \%$, and the fraction of grazing zooplankton production that was consumed by fish ranged between $2.8 \%$ and $56 \%$. The two variables are positively related $\left(r^{2}=\right.$ $0.74, P<.05$ ), which means that as a community shifts more toward having four trophic levels (phytoplankton $\rightarrow$ grazing zooplankton $\rightarrow$ zooplanktivorous fish $\rightarrow$ piscivores) rather than five (phytoplankton $\rightarrow$ grazing zooplankton $\rightarrow$ predatory zooplankton $\rightarrow$ zooplanktivorous fish $\rightarrow$ piscivores), the efficiency with which primary production is consumed by grazing zooplankton increases. This is consistent with what would be expected from trophic structure control of energy flow. Carpenter et al. (1992) reviewed data from 25 North American lakes and found the well-known statistical relationship between water-column phosphorus content and standing algal biomass. They also found, however, that algal biomass was significantly negatively correlated with both the biomass and the mean body size 
of grazing zooplankton. Because it is well-known that in the presence of fish zooplankton tend to be small in size and low in abundance, it appears that significant grazer control of the primary producers may be fairly widespread in lakes.

Several experimental studies have explored the effects of zooplanktivorous fish on zooplankton and phytoplankton abundances. For example, Vanni and Findlay (1990) found that, in enclosures containing yellow perch (Perca flavescens), zooplankton biomass was reduced and phytoplankton biovolume increased relative to controls (no fish). Similar results are reported by Bosselmann and Riemann (1986) for an enclosure-exclosure experiment. Morin et al. (1991) went one step further and showed that in replicate ponds containing zooplanktivorous fish, both planktonic and whole-pond primary productivity was about double that in similar ponds lacking fish. As in the previous two studies, zooplankton biomass was substantially lower in the presence of the fish (Hambright 1991). In each case, the fish enclosures or ponds received inputs of solar energy identical to that in the fishless ones, yet treatments with higher phytoplankton biomass and higher primary productivity contained lower biomass of the trophic level consuming it. This is strong evidence that the consumption efficiency of primary production by zooplankton is substantially greater in the absence of zooplankton-feeding fish than in their presence. A review by Liebold (1989) of 47 experiments of the type just discussed shows that these effects are quite general. Still, we suspect that the result of trophic-level manipulation will vary from system to system, depending on the species involved. Deep-bodied, spiny-rayed planktivorous fish are less vulnerable to piscivores than are those with shallow bodies and soft rays (Hambright et al. 1991). Some cyanobacteria are less edible than are other groups of algae (Porter 1977; Reynolds 1984). When present, each may determine trophic transfer efficiency as much or more than the state of higher trophic levels. These case-specific features may account for some of the exceptions to the general pattern noted by DeMelo et al. (1992) in their literature review. It is interesting and disconcerting, however, how often summaries of results given by DeMelo et al. (1992) differed from those in Liebold's (1989) comparable effort, even though many of the same references were used.

For terrestrial communities, McNaughton et al. (1992) pointed out that during years of population "outbreaks," the productivity of herbivorous insects may be substantially higher than it is in more typical years. It would be worth knowing in these instances how primary production responded. As in aquatic systems, experimental studies have documented significant effects of trophic structure on the standing biomass of different trophic levels. Holmes et al. (1979) excluded birds from sections of a temperate forest with netting and found that the numbers of Lepidoptera larvae increased substantially, which indicates predator control of the abundance of those herbivores. Other arthropod groups did not increase in the bird exclosures, however. It is interesting that at the typical prey population sizes present in that experiment, the proportion of caterpillar biomass removed by birds greatly exceeded the fraction typically consumed during caterpillar outbreaks. Thus, control of grazers by predators and grazer productivity (if McNaughton et al.'s 1992 result is general) can vary dramatically from year to year.

Predators apparently may also affect the dynamics of the primary producer 
trophic level, at least on a local scale. In one Australian forest community, the interspecific territoriality of the bell miner (Manorinia melanophrys) is so effective in excluding other insectivorous birds that the psyllid Homoptera increased to the point of defoliating the trees, because the bell miners were defending an area containing more psyllids than they could consume (Loyn et al. 1981). In a similar vein, Spiller and Schoener (1990) showed experimentally that removal of predatory lizards from island communities in the Bahamas typically resulted in an increase in herbivore damage to primary producers. The result is consistent with earlier observations by Schoener (1988) that leaf damage was elevated on islands naturally lacking lizards compared to islands where they were present. As in the case of freshwater pelagic communities, an intermediate predatory invertebrate trophic level may exist on these islands. Spiders are predators on the herbivores, while the lizards consume both herbivores and spiders. Spider population sizes were elevated in the absence of lizards (Schoener 1983), but their indirect effect on herbivory depended on the prey species considered.

In both terrestrial and freshwater pelagic communities, trophic structure plays a significant role in determining both the rate of energy fixation by the primary producers and the transfer efficiencies of this energy to higher trophic levels. These effects are not limited only to the communities just mentioned. Similar dynamics have been documented for the stream systems studied by Bowlby and Roff (1986) and Power (1990) and for the other aquatic systems such as marine kelp beds (Estes and Palmisano 1974). We believe that the regularities that we have suggested exist are determined first by the nature of the physical environment: substratum dominated versus pelagic. These qualities broadly dictate differences in the number of trophic levels typical of each. Second, differences in the number of trophic levels impose different transfer efficiencies because of the effects of alternating trophic control. Clearly, in continuing to explore the cause-effect relationship between trophic structure and energy flow, it will continue to pay to focus on the species constituting the dominant bulk of the biomass or exercising exceptional influence at each trophic level, the ecological and other biological properties of those species, and the constraints placed on the behaviors of species and communities by the physical properties of the environments in which they reside. The integration of the interaction among those species with measurements of the energetics involved will surely advance our understanding of ecological processes.

\section{ACKNOWLEDGMENTS}

The order of authors' names is alphabetical. This article is an outgrowth of a talk presented at a symposium in honor of the 75th anniversary of the founding of the Ecological Society of America entitled "Changing Perspectives on Some Long-standing Problems in Ecology." We thank R. B. Root and D. J. Shure for inviting us to think about this topic. R. W. Howarth, P. L. Marks, G. G. Mittelbach, R. T. Paine, G. A. Polis, M. E. Power, L. Real, R. B. Root, W. P. Sousa, E. E. Werner, and two anonymous referees provided invaluable criticism and advice. We thank K. D. Hambright for initially pointing out a role for gape 


\title{
limitation. Part of this research was supported by National Science Foundation grant BSR-8717134.
}

\author{
LITERATURE CITED
}

Alimov, A. F., V. V. Boullion, N. P. Finogenova, M. B. Ivanova, N. K. Kuzmitskaya, V. N. Nikulina, N. G. Ozeretskovskaya, and T. V. Zharova. 1972. Biological productivity of lakes Krivoe and Krugloe. Pages 39-56 in Z. Kajak and A. Hillbricht-Illkowska, eds. Productivity problems of freshwaters. Państwowe Wydawnictwo Naukowe, Warsaw.

Andronikova, I. N., V. G. Drabkova, K. N. Kuzmenko, N. F. Michailova, and E. A. Stravinskaya. 1972. Biological productivity of the main communities of Red Lake. Pages 57-71 in Z. Kajak and A. Hillbricht-Illkowska, eds. Productivity problems of freshwaters. Państwowe Wydawnictwo Naukowe, Warsaw.

Andrzejewska, L., and G. Gyllenberg. 1980. Small herbivore subsystem. Pages 201-267 in A. I. Breymeyer and G. M. Van Dyne, eds. Grasslands, systems analysis, and man. Cambridge University Press, New York.

Balogh, J. 1958. Lebensgemeinschaften der Landtiere. Akademie, Berlin.

Bendorf, J., ed. 1988. Biomanipulation. Limnologica 19:1-110.

Bent, A. C. 1937-1938. Life histories of North American birds of prey. Pts. 1, 2. Smithsonian Institution, Washington, D.C.

Bird, D. F., and J. Kalff. 1986. Bacterial grazing by planktonic algae. Science (Washington, D.C.) 231:493-495.

1987. Algal phagotrophy: regulating factors and importance relative to photosynthesis in Dinobryon (Chrysophyceae). Limnology and Oceanography 32:277-284.

Bosselmann, S., and B. Riemann. 1986. Zooplankton. Pages 199-236 in B. Riemann and M. Søndergaard, eds. Carbon dynamics in eutrophic, temperate lakes. Elsevier, Amsterdam.

Bowlby, J. N., and J. C. Roff. 1986. Trophic structure in southern Ontario streams. Ecology 67:1670-1679.

Bray, J. R. 1964. Primary consumption in three forest canopies. Ecology 45:165-167.

Briand, F., and J. E. Cohen. 1987. Environmental correlates of food chain length. Science (Washington, D.C.) 238:956-960.

1989. Response to Moore et al. Science (Washington, D.C.) 243:239-240.

Brooks, J. L., and S. I. Dodson. 1965. Predation, body size, and composition of plankton. Science (Washington, D.C.) 150:28-35.

Brown, J. H., and E. J. Heske. 1990. Control of a desert-grassland transition by a keystone rodent guild. Science (Washington, D.C.) 250:1705-1707.

Brylinsky, M. 1980. Estimating the productivity of lakes and reservoirs. Pages 411-453 in E. D. Le Cren and R. H. Lowe-McConnell, eds. The functioning of freshwater ecosystems. Cambridge University Press, Cambridge.

Brylinsky, M., and K. H. Mann. 1973. An analysis of factors governing productivity in lakes and reservoirs. Limnology and Oceanography 18:1-14.

Burns, T. P. 1989. Lindeman's contradiction and the trophic structure of ecosystems. Ecology 70:1355-1362.

Canfield, D. E. 1989. Sulfate reduction and oxic respiration in marine sediments: implications for organic carbon preservation in euxinic environments. Deep Sea Research 36:121-138.

Carpenter, S. R., ed. 1988. Complex interactions in lake communities. Springer, New York.

Carpenter, S. R., and J. F. Kitchell. 1988. Consumer control of lake productivity. BioScience 38:764-769.

Carpenter, S. R., J. F. Kitchell, J. R. Hodgson, P. A. Cochran, J. J. Elser, M. M. Elser, D. M. Dodge, D. Kretchmer, S. He, and C. M. von Ende. 1987. Regulation of lake primary productivity by food web structure. Ecology 68:1863-1876.

Carpenter, S. R., T. M. Frost, J. F. Kitchell, T. K. Kratz, D. W. Schindler, J. Shearer, W. G. Sprules, M. J. Vanni, and A. P. Zimmerman. 1992. Patterns of primary production and 
herbivory in 25 North American lake ecosystems. Pages 67-96 in J. Cole, S. Findlay, and G. Lovett, eds. Comparative analyses of ecosystems: patterns, mechanisms, and theories. Springer, New York.

Clements, F. E., and V. E. Shelford. 1939. Bioecology. Wiley, New York.

Coe, M. J., D. H. Cumming, and J. Phillipson. 1976. Biomass and production of large African herbivores in relation to rainfall and primary production. Oecologia (Berlin) 22:341-354.

Cohen, J. E. 1978. Food webs and niche space. Princeton University Press, Princeton, N.J.

Cole, J. J. 1985. Decomposition. Pages 302-310 in G. E. Likens, ed. An ecosystems approach to aquatic ecology: Mirror Lake and its environment. Springer, New York.

Coleman, D. C., and A. Sasson. 1980. Decomposer subsystem. Pages 609-655 in A. I. Breymeyer and G. M. Van Dyne, eds. Grasslands, systems analysis, and man. Cambridge University Press, New York.

Comstock, J. H. 1948. An introduction to entomology. Comstock, Ithaca, N.Y.

Cooper, S. D. 1988. The responses of aquatic insects and tadpoles to trout. Internationale Vereinigung für Theoretische und Angewandte Limnologie 23:1698-1703.

Coupland, R. T., and G. M. Van Dyne. 1979. Systems synthesis. Pages 97-106 in R. T. Coupland, ed. Grassland ecosystems of the world: analysis of grasslands and their uses. Cambridge University Press, Cambridge.

Cousins, S. 1987. The decline of the trophic level concept. Trends in Ecology \& Evolution 2:312-316.

DeMarco, V. G., R. W. Drenner, and G. W. Ferguson. 1985. Maximum prey size of an insectivorous lizard, Sceloporus undulatus garmani. Copeia 1985:1077-1080.

DeMelo, R., R. France, and D. J. McQueen. 1992. Biomanipulation: hit or myth? Limnology and Oceanography 37:192-207.

DeMott, W. R. 1988. Discrimination between algae and detritus by freshwater and marine zooplankton. Bulletin of Marine Science 43:486-499.

Diamond, J. 1986. Evolution of ecological segregation in the New Guinea montane avifauna. Pages 98-125 in J. Diamond and T. J. Case, eds. Community ecology. Harper, New York.

Dinesman, L. G. 1967. Influence of vertebrates on primary production of terrestrial communities. Pages 261-266 in K. Petrusewicz, ed. Secondary productivity of terrestrial ecosystems. Państwowe Wydawnictwo Naukowe, Warsaw.

Ducklow, H. W., D. A. Purdie, P. J. L. Williams, and J. M. Davies. 1986. Bacterioplankton: a sink for carbon in a coastal marine plankton community. Science (Washington, D.C.) 232:865-867.

Edwards, C. A., D. E. Reichle, and D. A. Crossley. 1970. The role of soil invertebrates in turnover of organic matter and nutrients. Pages 147-172 in D. E. Reichle, ed. Analysis of temperate forest ecosystems. Ecological Studies 1. Springer, New York.

Edwards, N. T., H. H. Shugart, Jr., S. B. McLaughlin, W. F. Harris, and D. E. Reichle. 1981. Carbon metabolism in terrestrial ecosystems. Pages 499-536 in D. E. Reichle, ed. Dynamic properties of forest ecosystems. Cambridge University Press, Cambridge.

Ehrlich, P. R., and J. Roughgarden. 1987. The science of ecology. Macmillan, New York.

Elton, C. 1927. Animal ecology. Sidgwick \& Jackson, London.

Estep,. M. L. F., and S. Vigg. 1985. Stable carbon and nitrogen isotope tracers of trophic dynamics in natural populations and fisheries of the Lahonton Lake system, Nevada. Canadian Journal of Fisheries and Aquatic Sciences 42:1712-1719.

Estes, J. A., and J. F. Palmisano. 1974. Sea otters: their role in structuring nearshore communities. Science (Washington, D.C.) 185:1058-1060.

Fenchel, T. 1988. Marine plankton food chains. Annual Review of Ecology and Systematics 19:19-38.

Flecker, A. S. 1992. Fish predation and the evolution of invertebrate drift periodicity: evidence from Neotropical streams. Ecology 73:438-448.

Forsberg, B. R. F. 1985. The fate of planktonic primary production. Limnology and Oceanography 30:807-819.

Fretwell, S. D. 1977. The regulation of plant communities by food chains exploiting them. Perspectives in Biology and Medicine Association of Peoria 20:169-185.

1987. Food chain dynamics: the central theory of ecology? Oikos 50:291-301.

Fry, B. 1986. Sources of carbon and sulfur nutrition for consumers in three meromictic lakes of New York State. Limnology and Oceanography 31:79-88. 
Gak, D. Z., V. V. Gurvich, I. L. Korelyakova, L. E. Kostikova, N. A. Konstantinova, G. A. Olivari, A. D. Primachenko, Ya. Ya. Tseeb, K. S. Vladimirova, and L. N. Zimbalevskaya. 1972. Productivity of aquatic organism communities of different trophic levels in Kiev Reservoir. Pages 445-455 in Z. Kajak and A. Hillbricht-Illkowska, eds. Productivity problems of freshwaters. Państwowe Wydawnictwo Naukowe, Warsaw.

Galoux, A. 1953. La chênaie sessiliflore de Haute Campine. Travaux. Série A. No. 8. Station de Recherches Groenendaal (Belgium).

Gleason, H. A. 1926. The individualistic concept of the plant association. Bulletin of the Torrey Botanical Club 53:1-20.

Greenway, P. 1965. Body form and behavioral types in fish. Experientia (Basel) 21:489-522 .

Hairston, N. G., Sr. 1985. The interpretation of experiments in interspecific competition. American Naturalist 125:321-325.

1989. Ecological experiments: purpose, design, and execution. Cambridge University Press, Cambridge.

Hairston, N. G., Sr., F. E. Smith, and L. B. Slobodkin. 1960. Community structure, population control, and competition. American Naturalist 94:421-425.

Hambright, K. D. 1991. Experimental analysis of piscivore-mediated trophic cascading effects in freshwater ponds. Ph.D. diss. Cornell University, Ithaca, N.Y.

Hambright, K. D., R. W. Drenner, S. R. McComas, and N. G. Hairston, Jr. 1991. Gape-limited piscivores, planktivore size refuges, and the trophic cascade hypothesis. Archiv für Hydrobiologie 121:389-404.

Hastings, A. 1988. Food web theory and stability. Ecology 69:1665-1672.

Hastings, H. M., and M. Conrad. 1979. Length and evolutionary stability of food chains. Nature (London) 282:838-839.

Hillbricht-Illkowska, A., Z. Gliwicz, and J. Spodniewska. 1966. Zooplankton production and trophic dependencies in the pelagic zone of two Masurian lakes. Internationale Vereinigung für Theoretische und Angewandte Limnologie 16:432-440.

Hobbie, J. E. 1980. Flux of carbon. Pages 5-9 in J. E. Hobbie, ed. Limnology of tundra ponds. Dowden, Hutchinson \& Ross, Stroudsburg, Penn.

Holmes, R. T., J. C. Schultz, and P. Nothnagle. 1979. Bird predation on forest insects: an exclosure experiment. Science (Washington, D.C.) 206:462-463.

Howarth, R. W., and J. M. Teal. 1980. Energy flow in a salt marsh ecosystem: the role of reduced inorganic sulfur compounds. American Naturalist 116:862-872.

Hrbacek, J. 1962. Species composition and the amount of zooplankton in relation to fish stock. Ceskoslovenské Akademie Ved, Rada Mathematickych a Príarodnich Ved 72:1-114.

Hutchinson, G. E. 1959. Homage to Santa Rosalia or Why are there so many kinds of animals? American Naturalist 93:145-159.

Kajak, A. 1980. Invertebrate predator subsystem. Pages 539-584 in A. I. Breymeyer and G. M. Van Dyne, eds. Grasslands, systems analysis, and man. Cambridge University Press, New York.

Keast, A., and D. Webb. 1966. Mouth and body form relative to feeding ecology in the fish fauna of a small lake, Lake Opinicon, Ontario. Journal of the Fisheries Research Board of Canada 23:1845-1874.

Kerfoot, W. C., and M. Lynch. 1987. Branchiopod communities: associations with planktivorous fish in space and time. Pages 367-378 in W. C. Kerfoot and A. Sih, eds. Predation: direct and indirect impacts on aquatic communities. University Press of New England, Hanover, N.H.

Kozlovsky, D. G. 1968. A critical evaluation of the trophic level concept. I. Ecological efficiencies. Ecology 49:48-60.

Krogius, F. V., E. M. Krokhin, and V. V. Menshutkin. 1972. The modelling of the ecosystem of Lake Dalnee on an electronic computer. Pages 149-164 in Z. Kajak and A. HillbrichtIllkowska, eds. Productivity problems of freshwaters. Państwowe Wydawnictwo Naukowe, Warsaw.

Kurihara, Y., and J. Kikkawa. 1986. Trophic relations of decomposers. Pages 127-160 in J. Kikkawa and D. J. Anderson, eds. Community ecology: pattern and process. Blackwell, Oxford.

Landry, M. R. 1977. A review of important concepts in the trophic organization of pelagic ecosystems. Helgoländer Wissenschaftliche Meeresuntersuchungen Biology 30:8-17. 
Levine, S. 1980. Several measures of trophic structure applicable to complex food webs. Journal of Theoretical Biology 83:195-207.

Lewis, W. M., Jr. 1976. Surface/volume ratio: implications for phytoplankton morphology. Science (Washington, D.C.) 192:885-887.

Liebold, M. A. 1989. Resource edibility and the effects of predators and productivity on the outcome of trophic interactions. American Naturalist 134:922-949.

Lieth, H. 1975. Primary production of the major vegetation units of the world. Pages 203-215 in H. Lieth and R. H. Whittaker, eds. Primary productivity of the biosphere. Ecological Studies 14. Springer, New York.

Likens, G. E. 1984. Beyond the shoreline: a watershed-ecosystem approach. Internationale Vereinigung für Theoretische und Angewandte Limnologie 22:1-22.

Lindeman, R. L. 1942. The trophic-dynamic aspect of ecology. Ecology 23:399-417.

Lodge, D. M., J. W. Barko, D. Strayer, J. M. Melack, G. G. Mittelbach, R. W. Howarth, B. Menge, and J. E. Titus. 1988. Spatial heterogeneity and habitat interactions in lake communities. Pages 181-208 in S. R. Carpenter, ed. Complex interactions in lake communities. Springer, New York.

Loyn, R. H., R. G. Runnalls, G. Y. Forward, and J. Tyers. 1981. Territorial bell miners and other birds affecting populations of insect prey. Science (Washington, D.C.) 221:1411-1413.

MacArthur, R. H. 1958. Population ecology of some warblers of northeastern coniferous forests. Ecology 39:599-617.

Martin, M. M. 1987. Invertebrate-microbial interactions: ingested fungal enzymes in arthropod biology. Comstock, Ithaca, N.Y.

Martinez, N. D. 1991. Artifacts or attributes? Effects of resolution on the Little Rock Lake food web. Ecological Monographs 61:367-392.

McNaughton, S. J., M. Osterheld, D. A. Frank, and K. J. Williams. 1989. Ecosystem-level patterns of primary productivity and herbivory in terrestrial habits. Nature (London) 341:142-144. 1992. Primary and secondary production in terrestrial systems. Pages 120-139 in J. Cole, S. Findlay, and G. Lovett, eds. Comparative analyses of ecosystems: patterns, mechanisms, and theories. Springer, New York.

Mittelbach, G. 1986. Predator-mediated habitat use: some consequences for species interactions. Environmental Biology of Fishes 16:159-189.

Moore, J. C., D. E. Walter, and H. W. Hunt. 1989. Habitat compartmentation and environmental correlates of food chain length. Science (Washington, D.C.) 243:238-239.

Morin, A., K. D. Hambright, N. G. Hairston, Jr., D. M. Sherman, and R. W. Howarth. 1991. Consumer control of gross primary production in replicate freshwater ponds. Internationale Vereinigung für Theoretische und Angewandte Limnologie 24:1512-1516.

Moskalenko, B. K., and K. K. Votinsev. 1972. Biological productivity and balance of organic substance and energy in Lake Baikal. Pages 207-226 in Z. Kajak and A. Hillbricht-Illkowska, eds. Productivity problems of freshwaters. Państwowe Wydawnictwo Naukowe, Warsaw.

Moulder, B. C., and D. E. Reichle. 1972. Significance of spider predation in the energy dynamics of forest-floor arthropod communities. Ecological Monographs 42:473-498.

Naiman, R. J., J. M. Mello, M. A. Lock, T. E. Ford, and S. R. Reice. 1987. Longitudinal patterns of ecosystem processes and community structure in a subarctic river continuum. Ecology 68:1139-1156.

Newton, I. 1979. The population ecology of raptors. Poyser, Birkhaustead, U.K.

Nixon, S. W. 1980. Between coastal marshes and coastal waters-a review of twenty years of speculation and research on the role of salt marshes in estuarine productivity and water chemistry. Pages 437-524 in P. Hamilton and K. B. McDonald, eds. Estuarine and wetland processes. Plenum, New York.

- 1982. Nutrient dynamics, primary production and fisheries yields of lagoons. Oceanologica Acta 4(suppl.):357-371.

Odum, E. P., C. E. Connell, and L. B. Davenport. 1962. Population energy flow of three primary consumer components of old-field ecosystems. Ecology 43:88-96.

Odum, H. T., and E. P. Odum. 1955. Trophic structure and productivity of a windward coral reef community on Eniwetok Atoll. Ecological Monographs 25:291-320. 
Oglesby, R. T. 1977. Relationships of fish yield to lake phytoplankton standing crop, production and morphoedaphic factors. Journal of the Fisheries Research Board of Canada 34:22712279.

Oksanen, L. 1988. Ecosystem organization: mutualism and cybernetics or plain Darwinian struggle for existence? American Naturalist 131:424-444.

1991. Trophic levels and trophic dynamics: a consensus emerging. Trends in Ecology \& Evolution 6:58-60.

Oksanen, L., S. D. Fretwell, J. Arruda, and P. Niemela. 1981. Exploitation ecosystems in gradients of primary production. American Naturalist 118:240-261.

Overbeck, J. 1972. Distribution pattern of phytoplankton and bacteria, microbial decomposition of organic matter and bacterial production in eutrophic, stratified lake. Pages 225-237 in Z. Kajak and A. Hillbricht-Illkowska, eds. Productivity problems of freshwaters. Państwowe Wydawnictwo Naukowe, Warsaw.

Pace, M. L. 1986. An empirical analysis of zooplankton community size structure across lake trophic gradients. Limnology and Oceanography 31:45-55.

Pace, M. L., G. B. McManus, and S. E. G. Findlay. 1990. Planktonic community structure determines the fate of bacterial production in a temperate lake. Limnology and Oceanography 35: $795-808$.

Paffenhofer, G.-A., and S. C. Knowles. 1980. Omnivorousness in marine planktonic copepods. Journal of Plankton Research 2:355-365.

Paine, R. T. 1988. Food webs: road maps of interactions or grist for theoretical development? Ecology 69:1648-1654.

Persson, L., G. Andersson, S. F. Hamrin, and L. Johansson. 1988. Predator regulation and primary production along the productivity gradient of temperate lake ecosystems. Pages 45-65 in S. R. Carpenter, ed. Complex interactions in lake communities. Springer, New York.

Peterson, B. J., and B. Fry. 1987. Stable isotopes in ecosystem studies. Annual Review of Ecology and Systematics 18:293-320.

Peterson, B. J., R. W. Howarth, and R. H. Garritt. 1985. Multiple stable isotopes used to trace the flow of organic matter in estuarine food webs. Science (Washington, D.C.) 227:1361-1363.

Pidgaiko, M. L., V. G. Grin', L. A. Kititsina, L. G. Lenchina, M. F. Polivannaya, O. A. Sergeeva, and T. A. Vinogradskaya. 1972. Biological productivity of Kurakhov's power station cooling reservoir. Pages 477-491 in Z. Kajak and A. Hillbricht-Illkowska, eds. Productivity problems of freshwaters. Państwowe Wydawnictwo Naukowe, Warsaw.

Pimm, S. L., and J. H. Lawton. 1977. The number of trophic levels in ecological communities. Nature (London) 268:329-331.

Polis, G. A. 1991. Complex trophic interactions in deserts: an empirical critique of food-web theory. American Naturalist 138:123-155.

Porter, K. G. 1977. The plant-animal interface in freshwater ecosystems. American Scientist 65:159-170.

Porter, K. G., H. Pearl, R. Hudson, M. Pace, J. Priscu, B. Riemann, D. Scavia, and J. Stockner. 1988. Microbial interactions in lake food webs. Pages 209-228 in S. R. Carpenter, ed. Complex interactions in lake communities. Springer, New York.

Powders, V. N., and W. L. Tietjen. 1974. The comparative food habits of sympatric and allopatric salamanders, Plethodon glutinosus and Plethodon jordani, in eastern Tennessee and adjacent states. Herpetologica 30:167-175.

Power, M. E. 1990. Effects of fish in river food webs. Science (Washington, D.C.) 250:811-814.

Rau, G. H., A. J. Mearns, D. R. Young, R. J. Olson, H. A. Schafer, and I. R. Kaplan. 1983. Animal ${ }^{13} \mathrm{C} /{ }^{12} \mathrm{C}$ correlates with trophic level in pelagic food webs. Ecology $64: 1314-1318$.

Reichle, D. E., and D. A. Crossley. 1967. Investigation on heterotrophic productivity in forest insect communities. Pages 563-587 in K. Petrusewicz, ed. Secondary productivity of terrestrial ecosystems. Państwowe Wydawnictwo Naukowe, Warsaw.

Reichle, D. E., R. A. Goldstein, R. I. Van Hook, and G. J. Dodson. 1973. Analysis of insect consumption in a forest canopy. Ecology 54:1076-1084.

Reichle, D. E., J. F. McBrayer, and S. Ausmus. 1975. Ecological energetics of decomposer inverte- 
brates in a deciduous forest and total respiration budget. Pages 283-292 in J. Van Ek, ed. Progress in soil zoology. Junk, The Hague.

Reynolds, C. S. 1984. The ecology of freshwater phytoplankton. Cambridge, Cambridge.

Riemann, B., and M. Søndergaard. 1986. Bacteria. Pages 127-197 in B. Riemann and M. Søndergaard, eds. Carbon dynamics in eutrophic, temperate lakes. Elsevier, Amsterdam.

Riemann, B., M. Søndergaard, L. Persson, and L. Johansson. 1986. Carbon metabolism and community regulation in eutrophic temperate lakes. Pages $267-280$ in B. Riemann and M. Søndergaard, eds. Carbon dynamics in eutrophic, temperate lakes. Elsevier, Amsterdam.

Risley, L. S., and D. A. Crossley. 1988. Herbivore-caused greenfall in the southern Appalachians. Ecology 69:1118-1127.

Rodhe, W. 1969. Crystallization of eutrophication concepts in Northern Europe. Pages 50-64 in Eutrophication: causes, consequences, correctives. National Academy of Sciences, Washington, D.C.

Rodin, L. E., and N. I. Basilevic. 1968. World distribution of plant biomass. Pages 45-50 in F. E. Eckhardt, ed. Functioning of terrestrial ecosystems at the primary production level. UNESCO, Paris.

Roughgarden, J., S. Gaines, and H. Possingham. 1988. Recruitment dynamics in complex life cycles. Science (Washington, D.C.) 241:1460-1466.

Ryther, J. H. 1969. Photosynthesis and fish population in the sea. Science (Washington, D.C.) $166: 72-76$.

Saunders, G. W., Jr. 1969. Some aspects of feeding in zooplankton. Pages 556-573 in Eutrophication: causes, consequences, correctives. National Academy of Sciences, Washington, D.C.

Saunders, P. T. 1978. Population dynamics and the length of food chains. Nature (London) 272:189-190.

Schoener, T. W. 1983. Spider populations: extraordinary high densities on islands without top predators. Science (Washington, D.C.) 219:1353-1355.

1988. Leaf damage in island buttonwood, Conocarpus erectus: correlations with pubescence, island area, isolation and the distribution of major carnivores. Oikos 53:253-256.

1989. Food webs from the small to the large. Ecology 70:1559-1589.

Shapiro, J., and D. I. Wright. 1984. Lake restoration by biomanipulation: Round Lake, Minnesota, the first two years. Freshwater Biology 14:371-383.

Sherr, E., and B. Sherr. 1988. Role of microbes in pelagic food webs: a revised concept. Limnology and Oceanography 33:1225-1227.

1991. Planktonic microbes: tiny cells at the base of the ocean's food webs. Trends in Ecology \& Evolution 6:50-54.

Sinclair, A. R. E. 1975. The resource limitation of trophic levels in tropical grassland ecosystems. Journal of Animal Ecology 44:497-520.

1985. Does interspecific competition or predation shape the African ungulate community? Journal of Animal Ecology 54:899-918.

Sinclair, A. R. E., and M. Norton-Griffiths, eds. 1979. Serengeti: dynamics of an ecosystem. University of Chicago Press, Chicago.

Singh, J. J., and S. R. Gupta. 1977. Plant decomposition and soil respiration in terrestrial ecosystems. Botanical Review 43:449-528.

Singh, J. S., M. J. Trlica, P. G. Risser, R. E. Redmann, and J. K. Marshall. 1980. Autotrophic subsystem. Pages 59-200 in A. I. Breymeyer and G. M. Van Dyne, eds. Grasslands, systems analysis, and man. Cambridge University Press, New York.

Slansky, F., Jr., and J. M. Scriber. 1985. Food consumption and utilization. Pages 87-163 in G. A. Kerkut and L. I. Gilbert, eds. Comprehensive insect physiology, biochemistry, and pharmacology. Pergamon, Oxford.

Slobodkin, L. B. 1960. Ecological energy relationships at the population level. American Naturalist 94:213-236.

1962. Growth and regulation of animal populations. Holt, Rinehart, \& Winston, New York.

Slobodkin, L. B., F. E. Smith, and N. G. Hairston. 1967. Regulation in terrestrial ecosystems, and the implied balance of nature. American Naturalist 101:109-124. 
Smith, F. E. 1969. Effects of enrichment in mathematical models. Pages 631-645 in Eutrophication: causes, consequences, correctives. National Academy of Sciences, Washington, D.C. 1975. Ecosystems and evolution. Bulletin of the Ecological Society of America 56:2-6.

Sorokin, Y. I. 1972. Biological productivity of the Rybinsk reservoir. Pages 493-503 in Z. Kajak and A. Hillbricht-Illkowska, eds. Productivity problems of freshwaters. Państwowe Wydawnictwo Naukowe, Warsaw.

Spiller, D. A., and T. W. Schoener. 1990. A terrestrial field experiment showing the impact of eliminating top predators on foliage damage. Nature (London) 347:469-472.

Sprules, W. G., and J. E. Bowerman. 1988. Omnivory and food chain length in zooplankton food webs. Ecology 69:418-426.

Stockner, J. G., and K. G. Porter. 1987. Microbial food webs and freshwater planktonic ecosystems. Pages 69-84 in S. R. Carpenter, ed. Complex interactions in lake communities. Springer, New York.

Strayer, D. 1991. Notes on Lindeman's progressive efficiency. Ecology 72:348-350.

Swift, M. J., O. W. Heal, and J. M. Anderson. 1979. Decomposition in terrestrial ecosystems. University of California Press, Berkeley.

Vanni, M. J., and D. L. Findlay. 1990. Trophic cascades and phytoplankton community structure. Ecology 71:921-937.

Vogt, K. A., C. C. Grier, and D. J. Vogt. 1986. Production, turnover, and nutrient dynamics of above-ground detritus of world forests. Advances in Ecological Research 15:303-377.

Werner, E. E., J. F. Gilliam, D. J. Hall, and G. G. Mittelbach. 1983. An experimental test of the effects of predation risk on habitat use in fish. Ecology 64:1540-1548.

Wetzel, R. D. 1983. Limnology. 2d ed. Saunders, Philadelphia.

1984. Detrital dissolved and particulate organic carbon functions in aquatic ecosystems. Bulletin of Marine Science 35:503-509.

1990a. Land-water interfaces: metabolic and limnological regulators. Internationale Vereinigung für Theoretische und Angewandte Limnologie 24:6-24.

$1990 b$. Detritus, macrophytes and nutrient cycling in lakes. Memorie dell'Instituto Italiano di Idrobiologia 47:233-249.

Wetzel, R. D., P. H. Rich, M. C. Miller, and H. L. Allen. 1972. Metabolism of dissolved and particulate detrital carbon in a temperate hard-water lake. Memorie dell'Instituto Italiano di Idrobiologia 29(suppl.): 185-244.

Whitaker, J. O., and D. C. Rubin. 1971. Food habits of Plethodon jordani metcalfi and Plethodon jordani shermani from North Carolina. Herpetologica 27:81-86.

Whittaker, R. H. 1975. Communities and ecosystems. 2d ed. Macmillan, New York.

Whittaker, R. H., and G. E. Likens. 1973. Carbon in the biota. Pages 281-300 in G. M. Woodwell and E. V. Pecan, eds. Carbon in the biosphere. U.S. Atomic Energy Commission, Washington, D.C.

Wiegert, R. G., and F. C. Evans. 1967. Investigations of secondary productivity in grasslands. Pages 499-518 in K. Petrusewicz, ed. Secondary productivity of terrestrial ecosystems. Państwowe Wydawnictwo Naukowe, Warsaw.

Winberg, G. G., V. A. Babitsky, S. I. Gavrilov, G. V. Gladky, I. S. Zakharenkov, R. Z. Kovalevskaya, T. M. Mikheeva, P. S. Nevyadomskaya, A. P. Ostapenya, P. G. Petrovich, J. S. Potaenko, and O. F. Yakushko. 1972. Biological productivity of different lake types. Pages 383-404 in Z. Kajak and A. Hillbricht-Illkowska, eds. Productivity problems of freshwaters. Państwowe Wydawnictwo Naukowe, Warsaw.

Wise, D. H. 1975. Food limitation of the spider Linyphia marginata: experimental field studies. Ecology 56:637-646.

1979. Effects of an experimental increase in prey abundance upon the reproductive rates of two orb-weaving spider species (Araneae: Araneidae). Oecologia (Berlin) 41:289-300.

1981. Inter- and intraspecific effects of density manipulations upon females of two orb-weaving spiders (Araneae: Araneidae). Oecologia (Berlin) 48:252-256.

Witcamp, M., and D. A. Crossley. 1966. The role of arthropods and microflora in breakdown of white oak litter. Paedobiologia 6:293-303. 
Yodzis, P. 1980. The connectance of real ecosystems. Nature (London) 284:544-545.

Yoshioka, T., E. Wada, and Y. Saijo. 1988. Analysis of lacustrine food web with natural carbon and nitrogen isotope ratios. Internationale Vereinigung für Theoretische und Angewandte Limnologie 25:573-578.

Zaret, T. M., 1980. Predation and freshwater communities. Yale University Press, New Haven, Conn.

Zaret, T. M., and R. T. Paine. 1973. Species introduction in a tropical lake. Science (Washington, D.C.) $182: 449-455$. 